University of Rhode Island

DigitalCommons@URI

Open Access Master's Theses

2002

\title{
MOISTURE INTERACTIONS WITH PHARMACEUTICALPOL YMERJC FILM COATINGS
}

Ravi S. Pappu

University of Rhode Island

Follow this and additional works at: https://digitalcommons.uri.edu/theses

\section{Recommended Citation}

Pappu, Ravi S., "MOISTURE INTERACTIONS WITH PHARMACEUTICALPOL YMERJC FILM COATINGS" (2002). Open Access Master's Theses. Paper 279.

https://digitalcommons.uri.edu/theses/279

This Thesis is brought to you for free and open access by DigitalCommons@URI. It has been accepted for inclusion in Open Access Master's Theses by an authorized administrator of DigitalCommons@URI. For more information, please contact digitalcommons-group@uri.edu. 
MOISTURE INTERACTIONS WITH PHARMACEUTICAL POLYMERIC FILM COATINGS

\title{
BY
}

RAVI S. PAPPU

\begin{abstract}
A THESIS SUBMITTED IN PARTIAL FULFILLMENT OF THE REQUIREMENTS FOR DEGREE OF MASTER OF SCIENCE
\end{abstract} IN PHARMACEUTICAL SCIENCES

UNIVERSITY OF RHODE ISLAND

2002 


\section{MASTER OF SCIENCE THESIS OF \\ RAVI S. PAPPU}

Approved:

Thesis Committee

Major Professor

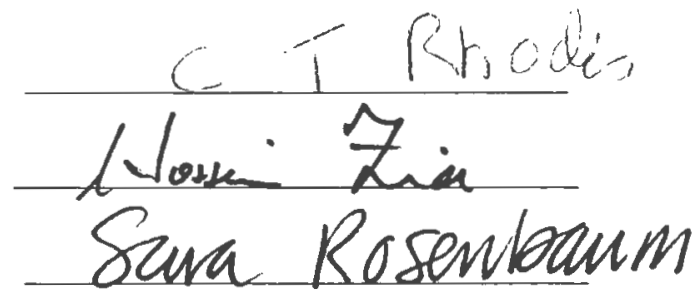

DEAN OF THE GRADUATE SCHOOL 


\begin{abstract}
It is a well-known fact that water can act as a detrimental variable in performance of pharmaceutical dosage forms. Derivatives of various starches and cellulose are widely used as excepients, generally in high proportions to the total amount making up the dosage form. A complete understanding of the uptake of moisture by cellulose polymers is important because moisture-polymer interaction affects various properties such as compressibility and stability. In this study 1) hydroxypropyl methylcellulose (HPMC), 2) modified HPMC (SEPPIC $\left.{ }^{\circledR}\right), 3$ ) microcrystaline cellulose containing carrageenan (Lusterclear ${ }^{\mathbb{k}}$ ) were used for studies of moisture polymer interaction. The interaction of moisture with these polymers was assessed using a simple and precise sorption system, which allows a rapid measure of uptake and loss of moisture. The effect of temperature on the sorption behavior of the film was also examined. All the three excepient films displayed sorption isotherms that were classified as type II (Langmuir) and demonstrated hysteresis during desorption. The BET model could be used restrictively but the GAB model fitted the data over the entire range of water activity under study. The Young \& Nelson model was successful in modeling hysteresis phenomenon but did not offer any mechanistic details.

Thermodynamic analysis of water-excepient film system has also been performed to understand the mechanistic details of moisture-excepient interactions. Partial molal free energies, enthalpies and entropies were calculated for the three
\end{abstract}


polymeric films. Results from the theoretical methods are useful for the predictive purpose where as thermodynamic studies offered mechanistic details of water-excepient interaction. A comparative study of the theoretical models and thermodynamic studies showed that the results from both the approaches were not always analogues to each other. In conclusion, 1) dynamic vapor sorption is very useful in investigation of waterexcepient interaction 2) it is necessary to apply both theoretical models and thermodynamic concepts for complete understanding of water-excepient interactions. 


\section{ACKNOWLEDGEMENTS}

I would like to thank my Major Professor Dr. Christopher Rhodes for his support and guidance during my association with him. I am grateful to Dr. Sara Rosenbaum and Dr. Hossein Zia for serving on my thesis committee and Dr. James kowalski for acting as the chairman of thesis committee. I wish to express my gratitude to Mr. Anand S. Achanta, Formulation scientist, at Glaxo-SmithKline Consumer Health Care, Parsippany, New Jersy for his encouragement, help and patience guidence during summer internship. I am grateful to Mr. Kenneth W. James, Head of Product Development- Worldwide, Dr. Prasad Adusumilli, Associate Director Mr. Stanley J. Lech, Associate director, and, Glaxo-SmithKline Consumer Health Care, Parsippany, NJ. Their generous financial support, access to laboratory, library and computing facilities of GSK are most gratefully appreciated. It would have been very difficult to complete thesis work.

It is not possible to list here all my friends to whom I am very grateful. I thank Sandeep Shah, Kiran Penumatcha, Roja Anandkumar, Aniruddha Shinde, Sourabh Mistry and Sridhar Noori. I also express my regards to my whole family. Naming them all is not possible here, but their care and love have been a source of strength to me. 


\section{PREFACE}

This document has been prepared in the format of the manuscript plan in accordance to section 11-3 of the Graduate Manual at the University of Rhode Island. This thesis has been divided into three sections.

Section I contains the statement of the problem and a brief introduction to the objectives of this research. Section II forms the central part of this thesis and is composed if three manuscripts written in the format prescribed by the scientific journal to which they have been or will be submitted for publication. Section III contains appendices that include the list of publications and experimental details useful for clearer understanding of the results described in the preceding manuscripts. A general summary of conclusions and bibliography for the entire thesis follows this section. 
TABLE OF CONTENTS

$\begin{array}{lc}\text { ABSTRACT } & \text { ii } \\ \text { ACKNOWLEDGEMENTS } & \text { iv } \\ \text { PREFACE } & \text { v } \\ \text { LIST OF TABLES } & \text { vii } \\ \text { LIST OF FIGURES } & \text { viii } \\ \text { SECTION I } & \\ \text { INTRODUCTION } & 1 \\ \text { OBJECTIVES } & 3 \\ \text { SECTION II } & \\ \text { MANUSCRIPT I } & 4 \\ \text { MANUSCRIPT II } & \\ \text { SECTION III } & 16 \\ \text { APPENDIX A } & 57 \\ \text { APPENDIX B } & 55 \\ \text { APPENDIX C } & 54\end{array}$




\section{LIST OF TABLES}

\section{MANUSCRIPT II}

Table1

Table2

29

Table3

30

Table 4

31

Table 5

32

Table 6

33 


\section{LIST OF FIGURES}

\section{MANUSCRIPT I}

Figure1

MANUSCRIPT II

Figure1

Figure 2

Figure 3

Figure 4

Figure 5

Figure6

Figure 7

Figure 8

Figure 9

Figure 10 
$\begin{array}{lr}\text { Figure } 11 & 44\end{array}$

$\begin{array}{ll}\text { Figure } 12 & 45\end{array}$

$\begin{array}{ll}\text { Figure 13 } & 46\end{array}$

$\begin{array}{lr}\text { Figure } 14 & 47\end{array}$

$\begin{array}{ll}\text { Figure } 15 & 48\end{array}$

$\begin{array}{lr}\text { Figure } 16 & 49\end{array}$

$\begin{array}{lr}\text { Figure } 17 & 50\end{array}$

$\begin{array}{ll}\text { Figure } 18 & 51\end{array}$

$\begin{array}{lr}\text { Figure } 19 & 52\end{array}$

$\begin{array}{ll}\text { Figure } 20 & 53\end{array}$ 


\section{SECTION I}

\section{INTRODUCTION}

Pharmaceutical solids as raw materials or dosage forms often come in contact with water during processes like wet granulation, crystallization and/or during storage i.e. because of exposure upon handling and storage to an atmosphere containing water vapor. Water associated with solids used pharmaceutically can significantly influence important physical, chemical and pharmaceutical properties such as dissolution, temperature, glass transition, compaction, powder flow and stability (1-3). Many precautions such as reduced contact with atmosphere or control of the relative humidity of atmosphere can be taken when water is perceived to be a problem, which add expense to the process. They also do not guarantee that there will be no further problems associated with moisture during the life of the product. So it is important to know as much as possible about the interaction of water with solids before planning to use them.

Derivatives of starch and cellulose are commonly employed as excepients for various purposes i.e., binders, adhesives, disintegrates and coating materials to provide physical and chemical protection to drugs. The quantity of moisture in excepients used pharmaceutically can greatly influence the appearance and performance of dosage form. (3). As these excepients are commonly employed in large amounts and known to take up and retain significant amount of moisture, it is important to understand moisture interactions of these excepients. In this context it is important to know some of the critical aspects concerning water-solid interaction like a) total amount

of water present b) how much of water will be sorbed or desorbed at a given relative 
humidity and temperature c) what is the thermodynamic state of water associated with solids at various levels of moisture content and d) what are the kinetics of moisture. uptake/loss. It is an objective of this thesis to develop a methodology and evaluate an data analysis techniques to answer above questions for films of pharmaceutical excepients that can form moisture barrier coatings. It is interesting to note that despite the extensive use of film coatings in pharmaceuticals, a detailed examination of interaction of water with excepient film has been not reported.

1) Ali Nokhodchi, James L. Ford, and Michel H.Rubinstein "Studies on the Interaction between Water and (Hydroxypropyl)methylcellulose" Jouranal of Pharmaceutical Sciences vol.86, No. 5, May 1997

2) Achanta A.S., "Hot melt coating:Water sorption behaviour of excipient films" pg 31, M.S thesis, Univ. of Rhode Island, USA (1999)

3) George Zografi and Mark. Kontny, "The Interaction of water with Cellulose- and Starch- Derived Pharmaceutical Excepients" Pharmaceutical Research, vol 3, No. 4, 1986

4) Labuza T.P., "Sorption phenomena in foods", Food Technology, 22: 263-272 (1968). 


\section{OBJECTIVES}

The salient objectives of this study have been listed below:

1) Develop a method to construct sorption/desorption isotherm for excepient film using dynamic vapor sorption technique (DVST). This includes optimization of sample preparation and handling, sample size, defining threshold value for reaching equilibrium and exposure time at each water activity.

2) Complete analysis of Isotherm using Langmuir, BET and GAB models. Evaluate hysteresis and distribution of moisture using Young and Nelson model.

3) Study influence of temperature on sorption/desorption behavior of excepient film. Estimate microrate constants for sorption and desorption and examine their variation with temperature.

4) Generate smoothed adsorption data from isotherms and use the data for complete thermodynamic analysis of water-excepient film systems. Perform a comparative evaluation of the results obtained from application of established models and thermodynamic analysis. 


\section{SECTION II}

\section{MANUSCRIPT I}

\section{REVIEW: The Interaction of Moisture with Cellulose- and Starch-Derived \\ Pharmaceutical Excipients}

1) Introduction:

Pharmaceutical solids as dosage forms often may come in contact with water during storage i.e. because of exposure upon handling and storage in an atmosphere containing water vapor. Water associated with solids used pharmaceutically can significantly influence important physical, chemical and pharmaceutical properties such as dissolution, temperature, glass transition, compaction, powder flow and stability $(1,2)$. Many precautions such as reduced contact with atmosphere or control of the relative humidity of the atmosphere can be taken when water is perceived to be a problem, which add expense to the process. They also do not guarantee that there will be no further problems associated with moisture during the life of the product (3). So it is important to know as much as possible about the interaction of water with solids before planning to use them.

Derivatives of starch and cellulose are commonly employed as excepients for various purposes i.e., binders, adhesives, disintegrants and coating materials, to provide physical and chemical protection to drugs (4). As these excepients are commonly employed and known to take up significant amount of moisture, it is important to understand moisture interactions of these excepients. In this context it is important to know some of the critical aspects concerning water-solid interaction like a) total amount of water present, b) how much of 
water will be sorbed or desorbed at a given relative humidity and temperature, c) what is the thermodynamic state of water associated with solids at various levels of moisture content and d) what are the kinetics of moisture uptake/loss. This importance only increases when the excepient function is to form a film that acts as a barrier to moisture ingress.

The literature reveals extensive work concerning sorption and desorption of water vapor in various fields such as paper (5), textiles (6), food (7). It is interesting to note that despite the extensive use of film coatings in pharmaceuticals, a detailed examination of the interaction of water with excepient film has been rarely reported. This review was compiled mainly focusing on cellulose and starch owing to their widespread usage in film coating.

\section{2) GENERAL PROPERTIES OF CELLULOSE AND STARCH}

Over the years volumes of studies have been reported regarding the physical and chemical properties of starch and cellulose. So overviews of physical and chemical properties that aid in understanding the nature of moisture interactions are reviewed below.

STARCH: Starch is a high molecular weight carbohydrate composed of $10-20 \%$ of amylose and $80-90 \%$ amylopectin. The glucose residues are in the form of branched chains in amylopectin and are arranged in linear fashion in amylose. The chief linkages of glucose units in starch, which gives starch structure and integrity of the system, are hydrogen bonds (8). Starch obtained from corn, which contains about $75 \%$ of dry weight of starch, is widely used as pharmaceutical 
excepient (9). Starch occurs as irregular, angular, white masses and contains polygonal or rounded grains from 3 to 35 microns in diameter.

CELLULOSE: Cellulose is anhydrides of $\beta$-glucose, possibly existing as long unbranched chains, consisting of 100 to $200 \beta$-glucose units. These chains are cross-linked by hydrogen bonds to produce supporting structure to cell walls of plants. X-ray diffraction studies have revealed that the crystalline regions have lengths of $600 \mathrm{~A}$ and width of about 50-150 A (10). In cellulose from higher plants crystalline units can be $2-3$ in nm length containing 15 chains. The percentage of crystallinity for cellulose obtained from woods and cotton is about $70 \%(11)$.

Microcrystalline Cellulose: Microcrystalline cellulose (MCC) is a purified, partially depolymerized cellulose prepared by treating alpha cellulose with mineral acid.

This is generally obtained from wood pulp. The specific surface area is in the range of $1-2 \mathrm{~m}^{2} / \mathrm{g}(11)$

Hydroxypropyl Methylcellulose: Hydroxypropyl methylcellulose (HPMC) is a propylene glycol ether of methylcellulose. It contains a substitution of $19-24 \%$ of methoxyl groups $\left(\mathrm{OCH}_{3}\right)$ and $4-12 \%$ of hydroxypropyl groups $\left(\mathrm{OC}_{3} \mathrm{H}_{6} \mathrm{OH}\right)$. It is a white, fibrous or granular powder. (9)

\section{3) SORPTION ISOTHERMS:}

The sorption isotherm is best described as a plot of mass of water taken up per unit mass of dry solid as a function of water vapor pressure $\mathrm{P}$, or water activity, $\mathrm{P} / \mathrm{P}_{\mathrm{o}}$, where $\mathrm{P}_{\mathrm{o}}$ is the vapor pressure of pure liquid water (12).Sorption is best 
studied starting with dried sample and exposing it to known relative humidity and desorption by starting with system containing sorbed water and reducing the relative humidity (3). Generally, moisture content at a particular relative humidity should be same, whether determined from sorption or desorption measurements. But, sorption-desorption isotherms commonly show hysteresis for certain type of systems such as microporous solids. Hysteresis generally is observed as the amount of water associated with solid on desorption is greater than the amount of originally sorbed water at a given relative humidity. A typical sorption isotherm for hydroxypropyl methylcellulose shows classical sigmoidal shape.

3.1) Langmuir Model

The classical approach in analyzing isotherms has been that of Langmuir. Langmuir's equation is based on the theory that molecules of gas or vapor are adsorbed on active sites and forms a monolayer when adsorbed onto the surface of solids $(12,13)$. The Langmuir isotherm is given by the equation

$$
y=y_{m} b p / 1+b p
$$

where $y=$ mass of the gas adsorbed per gram of adsorbent at pressure $p$ and constant temperature

$$
y_{m}=\text { mass of the gas that } 1 \text { gm of adsorbent can absorb when the }
$$
monolayer is complete $\mathrm{b}=\mathrm{k} 1 / \mathrm{k} 2$ where $\mathrm{k} 1$ and $\mathrm{k} 2$ are the constants that govern rate of adsorption and desorption respectively

A plot of $\mathrm{p} / \mathrm{y}$ Vs $\mathrm{p}$, a straight line results, the slope of which equals to $\mathrm{y}_{\mathrm{m}}$. Thus the mass of gas that one gram of adsorbent can adsorb when the monolayer is complete can be easily computed. In case of starches and cellulose, Langmuir 
model is useful for understanding the cursory nature of $\mathrm{k} 1$ and $\mathrm{k} 2$, but this model does not fit most of the isotherms because of the following assumptions:

a) The adsorption possible is more than just a monolayer

b) There are possible lateral interactions between the adsorbed molecules, whereas the model assumes no interactions.

c) The surface is composed of many varying sites with different attractions for water.

3.2) Brunauer, Emmett, and Teller Equation

Brunauer, Emmett, and Teller put forth the model most commonly used to describe the sigmoidal shaped isotherms. The BET model assumes that the first vapor molecule is adsorbed onto the adsorption site of the solid and is tightly bound where as the molecules beyond the first layer are assumed to behave like bulk liquid (7). The BET equation is

$$
\mathrm{W}=\mathrm{C}_{\mathrm{B}} \mathrm{W}_{\mathrm{M}}\left(\mathrm{P} / \mathrm{P}_{\mathrm{o}}\right) /\left[1-\left(\mathrm{P} / \mathrm{P}_{\mathrm{o}}\right)\right]\left[1-\left(\mathrm{P} / \mathrm{P}_{\mathrm{o}}\right)+\mathrm{C}_{\mathrm{B}}\left(\mathrm{P} / \mathrm{P}_{\mathrm{o}}\right)\right]
$$

$\mathrm{W}$ is the mass of vapor adsorbed per gram of dry solid at a relative pressure of $\mathrm{P} / \mathrm{P}_{\mathrm{o}}, \mathrm{W}_{\mathrm{M}}$ is the quantity of vapor adsorbed when each adsorption site has one molecule adsorbed to it, and $\mathrm{C}_{B}$ is a constant related to $\mathrm{H}_{1}$, the heat of adsorption of the first vapor molecule adsorbed to a site, and $\mathrm{H}_{\mathrm{L}}$, the heat of condensation of bulk adsorbate.

In general, the BET equation fits the adsorption data of starches and cellulose quite well over the range of relative pressure range of 0.3 to 0.4 , but at higher relative pressures it predicts more adsorption than is practically observed. This can be explained on the basis of assumptions made by this model which are: 
a) Sorption occurs only on specific sites

b) Infinite number of layers are adsorbed at a relative pressure of unity

c) The heat of sorption $\left(Q_{1}\right)$ for first layer is constant and $Q_{1}$ for layers above monolayer is equal to the heat of vaporization $\left(\Delta \mathrm{H}_{\mathrm{V}}\right)$.

In case of simple monolayer adsorption the BET equation reduces to Langmuir equation. In case of starches and cellulose where adsorbed moisture forms multilayers on the surface of solid is not a case of classical BET model. The BET equation is probably useful in predicting monolayer value and heat of adsorption.

There have been many attempts to modify the BET equation so that it would describe the sorption of water vapor over the entire range of relative pressure. Many of the modified BET models incorporated at least one fitting parameter that makes the computer fittings necessary. The meaning of the values obtained from these analyses often do not help in understanding the mechanisms of sorption from molecular viewpoint.

3.3) Guggenheim, Anderson, and deBoer Equation

The model developed by Guggenheim, Anderson, and deBoer, which is an extension BET model, fit the data over the entire range of relative pressure. The $\mathrm{GAB}$ model accounts for the intermediate state of water between the tightly bound molecules at the adsorption site and the condensed molecules in free state (1). The $\mathrm{GAB}$ equation is given as

$$
\mathrm{W}=\left[\mathrm{W}_{M} \mathrm{C}_{\mathrm{G}} \mathrm{K}\left(\mathrm{P} / \mathrm{P}_{\mathrm{o}}\right)\right] /\left[\left(1-\mathrm{K}\left(\mathrm{P} / \mathrm{P}_{\mathrm{o}}\right)\right)\left(1-\mathrm{K}\left(\mathrm{P} / \mathrm{P}_{\mathrm{o}}\right)+\mathrm{C}_{\mathrm{G}} \mathrm{K}\left(\mathrm{P} / \mathrm{P}_{\mathrm{o}}\right)\right)\right]
$$


Where $\mathrm{P}, \mathrm{Po}, \mathrm{W}$, and $\mathrm{W}_{\mathrm{M}}$ are the same parameters used in BET equation, and $\mathrm{K}, \mathrm{C}_{\mathrm{G}}$ are defined as

$$
\mathrm{K}=\mathrm{B} \exp \left[\mathrm{H}_{\mathrm{L}}-\mathrm{H}_{\mathrm{M}} / \mathrm{RT}\right] \text { and } \mathrm{C}=\mathrm{D} \exp \left[\mathrm{H}_{1}-\mathrm{H}_{\mathrm{M}} / \mathrm{RT}\right]
$$

Where $\mathrm{B}, \mathrm{D}$ are constants, $\mathrm{H}_{\mathrm{M}}$ is the heat of adsorption of intermediately bound layer, $\mathrm{H}_{1}$ is the heat of adsorption of the first vapor molecule adsorbed to a site, and $\mathrm{H}_{\mathrm{L}}$ is the heat of condensation of bulk adsorbate. However, the BET and GAB models do not give an insight to the nature of the water molecules binding to the primary binding sites of starch and cellulose (14).

\section{4) Young and Nelson Equation (YNM)}

The sorption isotherms of starch and cellulose usually show hysteresis. There are numerous theories that have been proposed to explain this phenomenon. The most extensively used model is the one proposed by Young and Nelson. The YNM was developed for the biological material in an attempts to relate equilibrium water vapor sorption to relative humidity (15). YNM differentiates three types of water: a bound monolayer, external water and absorbed or internal water. YNM is based on the assumption that the water bound on the outer surface determines movement of water to and from the biological cells (15). The mathematical equations describing YNM are:

$\theta=a_{w} /\left(a_{w}+\left(1-a_{w}\right) E\right)$

$\varphi=\mathrm{a}_{\mathrm{w}}(\theta)$

$\alpha=-\left(a_{w} \cdot E\right) /\left(E-\left((E-1) \cdot a_{w}\right)\right)+(E 2 /(E-1)) \ln \left(E-\left((E-1) \cdot a_{w}\right) / E\right)-(E+1) \ln \left(1-a_{w}\right)$ 
$\mathrm{M}_{\mathrm{S}}=\mathrm{A}(\theta+\alpha)+\mathrm{B} \varphi$

$M_{d}=A(\theta+\alpha)+B \theta a w_{\max }$

where $M_{s}$ and $M_{d}$ are the moisture contents of the material during sorption and desorption conditions, $\theta$ is the fraction of surface covered by a monomolecular layer, $\varphi$ is the fraction of the surface covered by multimolecular surface, $\alpha$ total amount of moisture in a multilayer, a wmax is the maximum water activity condition and $\mathrm{A}, \mathrm{B}$ and $\mathrm{E}$ are the parameters unique to each substance. $\mathrm{A} . \theta$ is the amount of monomolecular layer of water on surface, A $(\theta+\alpha)$ multimolecular layer of moisture and B. $\varphi$ is the amount of moisture sorbed internally.

The parameters A, B, E have to be carefully interpreted because YNM presume the material under consideration to be a biological cell. So the terms outer sorbed and inner absorbed has to be clearly understood.

\section{4) CONCLUSIONS}

Although, it is well established that the moisture associated with excepients significantly effect the physical and chemical properties of the drug, the mode of transfer of water from excepient to drug is not clear. A complete knowledge of sorption isotherms of all the ingredients will allow one to identify the amount of water that is equilibrating with other ingredients in vapor state. It was seen that the model which accounts for the for the water in three states: tightly bound outer layer, intermediate or less tightly bound layer and bulk water, can explain the sorption/desorption data for cellulose and starch materials. The hysteresis could be modeled using YNM model, although physical interpretation of models is not definite. Though the model described here are successful in interpreting the data 
they do not give any insight to the mechanistic details of moisture-excepient interaction. 


\section{REFERENCES}

1) Achanta A.S., Adusumilli P.S., James K.W. and Rhodes C.T., " Development of hot melt coating methods", Drug Development \& Industrial Pharmacy, 23: 441-449 (1997).

2) Achanta A.S., "Hot melt coating:Water sorption behaviour of excipient films" pg 31, M.S thesis, Univ. of Rhode Island, USA (1999).

3) United States Pharmacopeia 23/National Formulary 18, The United States Pharmacopeial Convention, Rockville (1995).

4) Lachman L., Lieberman H.A. and Kanig J.L, The Theory and Practice of Industrial Pharmacy, Third Edition, Published by Lea \& Febiger, Philadelphia (1986).

5) Rockland L.B., and Stewart G.F.,, Water Activity: Influences on Food Quality, Academic Press, New York, 1981.

6) Urquart A.R., and Willams A.M., J. Textile Inst., 15:T559-T572(1924).

7) Scallan A.M., In Transactions of Symposium on Fiber-Water Interactions in Paper-Making, The Bristish Paper and Industry federation, London. 1977, pp. 9-29.

8) Honeymoon J., Recent Advances in the chemistry of Cellulose and Starch, Interscience, New York (1959).

9) Wilson and Gisvold's textbook of organic medicinal and pharmaceutical chemistry, 10 edition, published by Lippincott-Raven (1998).

10) Stamm A.J., Wood and Cellulose Science, Ronald press, New York (1964).

11) Zografi G. and Mark. Kontny, "The Interaction of water with Cellulose- and Starch- Derived Pharmaceutical Excepients" Pharmaceutical Research, vol 3, No. 4, 1986.

12) Labuza T.P., "Sorption phenomena in foods", Food Technology, 22: 263-272 (1968).

13) Martin A. and Bustamante.P., Physical Pharmacy, Fourth Edition, Published by Lea \& Fbiger, Philadelphia (1993).

14) Brittain H.G., Physical Characterization of Pharmaceutical Solids, Published by Marcel Dekker, New York (1995). 
15) Young J.H. and Nelson G.L., "Research of hysteresis between sorption and desorption isotherms of wheat", Transactions of the American Society of Agricultural Engineers, 10: 756-761 (1967). 


\section{FIG1: Structure of cellulose}

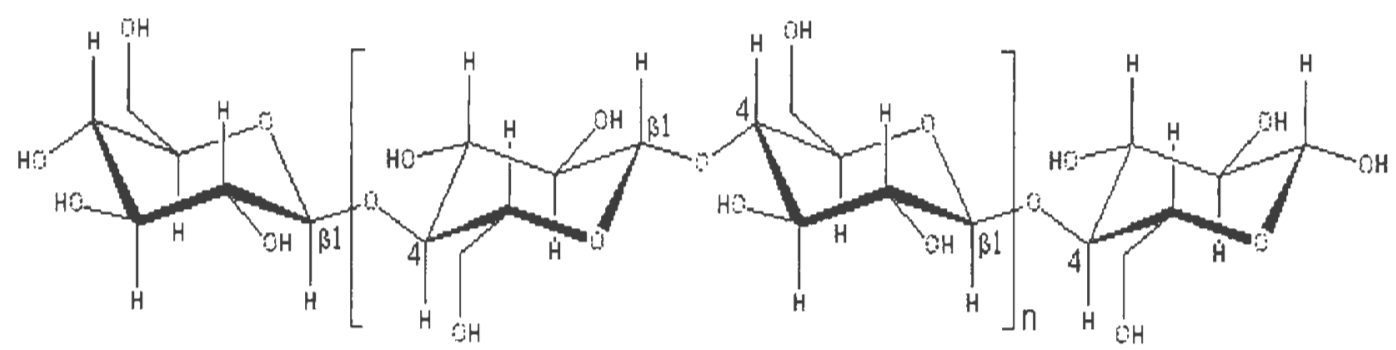




\title{
MANUSCRIPT II \\ Water Sorption Behavior of Excipient Films
}

\begin{abstract}
Information on the interaction between moisture and polymers is indispensable for manufacturing of many solid dosage forms since water polymer interaction affects various properties such as compressibility and stability. In this study 1)hydroxypropyl methylcellulose (HPMC), 2)modified HPMC(SEPPIC $\left.{ }^{\circledR}\right)$, and 3) microcrystaline cellulose containing carrageenan gum (Lusterclear ${ }^{(8)}$ ) were used for studies of moisture polymer interaction. The interaction of moisture with these polymers was assessed using a fully automated gravimetric sorption system, which allows a rapid measure of uptake and loss of moisture. The effect of temperature on the sorption behavior of the film was also examined. All the three excepient films displayed sorption isotherms that were classified as type II (Langmuir) and demonstrated hysteresis during desorption. Detailed analysis of the data shows some departure from simple Langmuir type behavior. The BET model could be used restrictively but the GAB model fitted the data over the entire range of water activity under study. Thermodynamic analysis of waterexcepient film system has also been performed to elucidated the mechanistic details of moisture-excepient interactions. Partial molal free energies, enthalpies and entropies were calculated for the three polymeric films. A comparative study of the theoretical models and the experimental thermodynamic studies showed that the results from the two approaches were not always in agreement.
\end{abstract}


Introduction

The physiochemical properties of pharmaceutical solids are critically dependent on the presence of moisture (1). Pharmaceutical solids as dosage form most often are exposed to water during storage. One method to protect drug products from moisture is to coat them with polymers that act as barrier to moisture ingress. The quantity of moisture in excepients used pharmaceutically can greatly influence appearance and performance of dosage form (2). So it is important to understand interaction of water with excepient films before making strategies to use them. From literature review, hydroxypropyl methylcellulose (HPMC) was a found to be suitable excepient, which acts as barrier to moisture ingress, and included in this study. Novel formulation of HPMC and microcrystalline cellulose (MCC) that are being commercially promoted as moisture protective film coating excepients are also used.

The traditional pharmaceutical method use to determine moisture sorption properties i.e., storing the sample in chambers of various relative humidities and removing them to measure weight gained or lost, is both tedious and imprecise and involves prolonged periods of time (3). So a new technique, the Dynamic Vapor Sorption technique (DVST), reported by Achanta et al. (4 ) was used to measure uptake and loss of moisture. The Dynamic Vapor Sorption apparatus (DVS) consists of two programmable constant humidity chambers and an ultra sensitive microbalance in a temperature-controlled oven. The material specimen was suspended from the microbalance and a carrier gas was passed over the 
sample at specific relative humidity. DVS suite software records the change in mass with time data.

It is the objective of this study was to characterize the sorption/desorption behavior of the excepient films and to study the nature of their interaction with water as function of temperature. Established theoretical models were employed for this purpose. A second objective of this study is to investigate thermodynamics water-excepient systems that will elucidate the process of water sorption/ desorption.

\section{2) Materials and methods}

Hydroxypropyl methylcellulose (Methocel ${ }^{\circledR}$, Lot \# OA14012N22) was obtained from Dow chemical company, Midland, Michigan. Hydroxypropyl methyl cellulose with a hydrophobic plasticizer, stearic acid, (Seppic ${ }^{\oplus}$, Lot \# 11651 ) and microcrystalline cellulose containing carrageenan gum (Lusterclear ${ }^{\$}$, Lot \# XN118) were obtained from Seppic Inc, 75, Quiad'orsay-75321, Paris and FMC biopolymer, Newark, DE respectively. To cast films $10 \% \mathrm{w} / \mathrm{w}$ dispersions were prepared in deionized water for all the three polymers. $5 \mathrm{gm}$ of this dispersion was taken in a flat, circular aluminum pan normally used for loss on drying determinations and dried in an oven at $333 \mathrm{~K}$ for 4 hours.

A DVST method using DVS-2000 (Surface Measurements Systems Limited, N.A., Coopersburg, USA) was used to study the moisture interactions of these films. The humidity probes were calibrated as prescribed by manufacturer to cover a water activity $\left(a_{w}\right)$ of $0.00,0.17,0.34,0.51,0.68$ and 0.85 .The balance was calibrated before each use. 


\section{3) Results and discussion}

\subsection{Construction of isotherms}

Rectangular specimens of each polymeric film prepared were taken and attached to microbalance using paper clip. Paper clips are used instead of normal glass pans to hold the sample to expose maximum surface area to water activity. The conditions for reaching equilibrium is predefined using the DVS analysis suite, as the percent change in mass per minute computed over any consecutive ten minutes fall below the defined threshold value. A threshold value of $0.002 \% / \mathrm{min}$ was define for the three films, where as USP suggests that weighing should be continued until consecutive readings show a mass change of $0.25 \% /$ hour for equilibrium moisture determinations. Using the change in mass with time data recorded by DVS analysis suite the isotherms are constructed for the three polymeric films at $\mathrm{T}=293,303$ and $313 \mathrm{~K}$. The isotherms constructed by plotting the equilibrium moisture content vs. water activity are shown in figures 1,2 and 3. The isotherms show sigmoidal shapes, which suggests that they come under type II isotherms according to Martin (5). Martin stated that the BET constant $\left(\mathrm{C}_{\mathrm{BET}}\right)$ for type II isotherms should be greater than 2 and this type of isotherms occur when gases are adsorbed onto nonporous solids to form a monolayer followed by multilayer formation.

3.2) Estimation of micro rate constants

Sorption micro rate constant $\left(\mathrm{k}_{1}\right)$ and desorption micro rate constant $\left(\mathrm{k}_{2}\right)$ were described by Langmuir as governing the sorption and desorption process respectively (6). A plot of mass versus time was constructed at each water activity 
and the slope of tangent drawn to the initial portion of this plot gives the estimate of these constants. The estimated values of $k_{1}$ and $k_{2}$ for HPMC, modified HPMC, and MCC are tabulated in tables 1, 2, and 3.

Estimated values of $k_{1}$ and $k_{2}$ are of the same order for the three polymeric films. The data for both the micro rate constants increased with increasing water activity for the three polymeric films. The estimates for MCC followed fashion that is more orderly and increased with increase in temperature. The Langmuir model does not fit the data of the three polymeric films. This can be explained on the basis of underlying assumptions of the model. Moreover, it is not correct to calculate desorption micro rate constants as explained when the data shows hysteresis. The objective of these calculations is to understand the cursory nature of microrate constants.

\section{3) BET and GAB analysis}

The isotherms of HPMC, modified HPMC and MCC at T=293, 303and $313 \mathrm{~K}$ were analyzed using both BET and GAB models. The BET model satisfactorily fits the data of HPMC, modified HPMC and MCC at three temperatures, over a restricted range of water activity $\left(a_{w}\right)(0.17$ to 0.51$)$ but does not satisfactorily define data of the three polymeric films at other water activities.

The BET constants are grater than 2 for all the three polymers, as stated by Martin. The BET constant $\left(\mathrm{C}_{\mathrm{BET}}\right)$, the constants due to site interaction $\left(\mathrm{H}_{\mathrm{S}}\right)$ and monolayer values $\left(V_{m}\right)$ are shown in table 4 .

The GAB model, which is an extension of BET model, takes into account an extra layer of sorbed vapor intermediate to the monolayer and the bulk water using an 
additional parameter $\mathrm{K}$. The GAB model fits the data for all the three polymeric films at all the three temperatures over the entire range of water activity understudy. To calculate various parameters of $\mathrm{GAB}$ model i.e., $\mathrm{K}, \mathrm{C}_{\mathrm{GAB}}, \mathrm{V}_{\mathrm{M}}$ a plot between reciprocal of equilibrium moisture content and water activity was constructed and analyzed using nonlinear regression analysis software (Sigma plot, version 4.0, SPSS Inc., Chicago, USA). The results of this non-linear regression are provided in table 5.

The monolayer values predicted using GAB model for the three polymeric films are almost the same and appear to be temperature independent. The monolayer values obtained from $\mathrm{GAB}$ model are in agreement with the values of monolayer obtained from BET model.

3.4) Analysis of hysteresis

The Young and Nelson model (YNM) is the extensively used model to analyze hysteresis. Young and Nelson correlated the equilibrium moisture sorption and desorption of biological material to relative humidity. They distinguished three basic mechanisms of water uptake 1) monomolecular layer of water on surface 2) multimolecular layer of external water 3) moisture absorbed. The total water sorption can be explained by YNM using the two equations:

$$
\begin{aligned}
& \mathrm{M}_{\mathrm{S}}=\mathrm{A}(\theta+\alpha)+\mathrm{B} \varphi \\
& \mathrm{M}_{\mathrm{d}}=\mathrm{A}(\theta+\alpha)+\mathrm{B} \theta \mathrm{a}_{\mathrm{Wmax}} \\
& \theta=\mathrm{a}_{\mathrm{W}} /\left(\mathrm{a}_{\mathrm{w}}+\left(1-\mathrm{a}_{\mathrm{w}}\right) \mathrm{E}\right) \\
& \varphi=\mathrm{a}_{\mathrm{w}}(\theta) \\
& \alpha=-\left(\mathrm{a}_{\mathrm{w}} \cdot \mathrm{E}\right) /\left(\mathrm{E}-\left((\mathrm{E}-1) \cdot \mathrm{aw}_{\mathrm{w}}\right)\right)+(\mathrm{E} 2 /(\mathrm{E}-1)) \ln \left(\mathrm{E}-\left((\mathrm{E}-1) \cdot \mathrm{a}_{\mathrm{w}}\right) / \mathrm{E}\right)-(\mathrm{E}+1) \ln \left(1-\mathrm{a}_{\mathrm{w}}\right)
\end{aligned}
$$


where $M_{s}$ and $M_{d}$ are the moisture contents of the material during sorption and desorption conditions, $\theta$ is the fraction of surface covered by a monomolecular layer, $\varphi$ is the fraction of the surface covered by multimolecular surface, $\alpha$ total amount of moisture in a multilayer, $\mathrm{a}_{\mathrm{w} \max }$ is the maximum water activity condition and $\mathrm{A}, \mathrm{B}$ and $\mathrm{E}$ are the parameters unique to each substance. A. $\theta$ is the amount of monomolecular layer of water on surface, $A(\theta+\alpha)$ multimolecular layer of moisture and B. $\varphi$ is the amount of moisture sorbed internally(7). A nonlinear regression analysis procedure was developed to fit the sorption and desorption data of three polymeric films and also to calculate the A, B and E parameters. The SAS statistical software (Version6.12, SAS Institute Inc., Cary , USA) was used for this purpose. The estimated parameters for HPMC, modified HPMC and MCC at various temperatures are given in table 6.

In almost all the cases the YNM predicted showed an excellent fit to the actual data. The parameters A, B of HPMC and modified HPMC are almost same suggesting that the hydrophobic plasticizer added to HPMC did not affect the amount of monolayer moisture or the internally sorbed moisture. The term "internally absorbed" moisture has to be carefully understood in the current situation. As the YNM is basically proposed for biological material, internally sorbed moisture meant the moisture that crossed the cell wall. But in the present situation it perhaps be interpreted as the water that formed some sort of chemical bonds with the adsorbate molecules. Further, YNM offers only a analytical solution to the hysteresis phenomenon, but not the mechanistic solutions. 
Therefore the physical significance of the parameters is subjected to further evaluation.

3.5) Free energy changes

The relative partial molal free energy change of water $\left(\Delta \mathrm{G}_{2}\right)$ for HPMC, modified HPMC and microcrystaline cellulose are shown in figuers5, 6, and 7 respectively. It can be seen that the $\Delta G_{2}$ is larger for dry excepient films as might be expected. For all the three polymeric films, a point of inflection can be observed at almost all the temperatures. For HPMC at $303 \mathrm{~K}$ it can be observed between 0.35 and 0.4 moles of water per $100 \mathrm{~g}$ of film. Other than the point of inflection we can see a monotonous curve. This point of inflection perhaps suggests the completion of monolayer formation.

The free energies of adsorption $(\Delta \mathrm{G})$, weighted relative partial molal free energy change of water $\left(n_{2} \Delta G_{2}\right)$ and excepient film $\left(n_{1} \Delta G_{1}\right)$ of the three polymers are shown on figures 8,9 , and 10 . The value of $n_{2} \Delta G_{2}$ gives the contribution of water to the overall free energy change associated with adsorption and $n_{1} \Delta G_{1}$ shows the contribution of the excepient film. For all the three films $\mathrm{n}_{2} \Delta \mathrm{G}_{2}$ curves can be divided into three regions: region 1 represents the decreasing part, region 2 represents the plateau region followed by region 3 where the values of $n_{2} \Delta G_{2}$ increase. These three regions may represent completion of monolayer, formation of intermediate layers and formation of bulk layer of water respectively. Also, in region 1 the film surface is believed to be restructured due to the interaction with water and this restructured surface serves as substrate for 
subsequent adsorption. The minima of this region indicate the affinity of excepient to water.

Weighted relative partial molal free energy change of excepient film $\left(n_{1} \Delta G_{1}\right)$ for all the three-excepient films showed almost a linear decrease with increase in water activity. It has been shown that this perturbation becomes evident after saturation of certain sites $(8,9)$. Thus it can be concluded that the excepient films are not inert. For the three polymeric films $\Delta \mathrm{G}$ showed a monotonic decrease without any inflections. The smooth decrease in the curve indicate the importance of individual examination of relative contributions of water and excepient films.

3.6) Isostearic heats of adsorption

The relative partial molal enthalpies of adsorbed water $\left(\Delta \mathrm{H}_{2}\right)$ for all the three films are in figures 11,12 , and 13 . At $\mathrm{T}=313 \mathrm{~K}$ for HPMC and modified HPMC, 6 exothermic maximas can be observed where as at $\mathrm{T}=303 \mathrm{~K}$ both of them showed 5 exothermic maximas. The first exothermic maxima of about 20 $\mathrm{KJ} / \mathrm{mol}$ at $\mathrm{T}=313 \mathrm{~K}$ for HPMC suggests that each water molecule is involved in two hydrogen bonds (10). MCC at both temperatures showed less exothermic maximum than the other excepient films. Exothermic maxima indicate the completion of monolayer. Integral enthalpy of adsorption $(\Delta \mathrm{H})$ and weighed relative partial molal enthalpies of excepient film $\left(n_{1} \Delta H_{1}\right)$ and water $\left(n_{2} \Delta H_{2}\right)$ are calculated and figures 14, 15 and 16 present these functions for HPMC, modified HPMC and MCC respectively at $\mathrm{T}=313 \mathrm{~K}$. The $\Delta \mathrm{H}$ function is smooth and shows a decrease, while $n_{1} \Delta \mathrm{H}_{1}$ and $n_{2} \Delta \mathrm{H}_{2}$ are more informative because of the inflection 
points. For HPMC at $303 \mathrm{~K} \mathrm{n}_{2} \Delta \mathrm{H}_{2}$ function attains a minima and a progressive decrease is seen up to $n_{2}=0.4 \mathrm{~mol} / 100 \mathrm{~g}$ of film and then increases rapidly. The $\mathrm{n}_{1} \Delta \mathrm{H}_{1}$ first attains maxima and a gradual decrease is observed from then. A similar pattern is seen for HPMC at $313 \mathrm{~K}$.

3.7) Entropy changes

Relative partial molal entropies $\left(\Delta S_{2}\right)$ has been calculated for HPMC, modified HPMC and MCC and shown in figures 17, 18 and 19. The initial decrease in the curves for all the three polymeric films suggests lack of mobility of water as the water is tightly bound to the adsorbate molecules. As more water is sorbed, water molecules form cluster around the tightly bound water, which increases the mobility of water. The entropy profiles are comparable to the enthalpies discussed earlier. This can be justified as the $\Delta \mathrm{G} 2$ curve seen earlier shown a monotonus decrease with only very few inflection points on the top and then flattened out.

3.8) Comparative evaluation:

The comparative study of theoretical model and thermodynamic model was conducted to understand clearly the mechanism of moisture interaction and to verify the nature of data obtained from these methods. Although the theoretical models described above are successful in analytically fitting the data, thermodynamic analysis of the data is very useful in clarifying the water-film interactions at molecular level (10). The theoretical models assumed that the excepient film is inert in the sorption/desorption process that is proven wrong by the thermodynamic methods. GAB model satisfactorily fits the data of all the 
three polymeric films, which proposes the presence of three types of water, has been confirmed by the thermodynamic studies. The hypothesis of hydrogen bond formation between water and adsorbate molecules and the energy values corresponding to exothermic maximas, which aid in the calculation of number of hydrogen bonds, confirm the hysteresis phenomenon.

\section{4) Conclusions}

DVST has proven to be a useful instrument for fast, convenient and accurate determination of moisture interactions of excepients. Results from both the theoretical models as well as thermodynamic methods shown the presence of three different forms of water: monolayer, intermediate less tightly bound water and the bulk water. It has been shown that the hysteresis, which is formed due to hydrogen bonding between water and adsorbate molecules, can be modeled using YNM. The assumption of theoretical models that the excepients are inert in vapor sorption processis of dubious validity for the system reported in this paper. Theoretical models can be used for the predictive and analytical purpose whereas thermodynamic studies help in understanding mechanistic details of moisture interactions with excepient films.

Acknowledgements

The generous financial support, access to laboratory, library and computer facilities of Glaxo SmithKline Consumer Healthcare was gratefully acknowledged. 


\section{REFERENCES}

1) Zografi G. and Mark. Kontny, "The Interaction of water with Cellulose- and Starch- Derived Pharmaceutical Excepients" Pharmaceutical Research, vol 3, No. 4, (1986).

2) Nokhodchi, A., Ford, J.L., and Rubinstien, M.H. Studies on the interaction between Water and (Hydroxypropyl) methylcellulose, Journal of Pharmaceutical sciences vol.86, no.5 (1997).

3) United States Pharmacopeia. 23/National Formulary 18, The United States Pharmacopeial Convention, Rockville (1995).

4) Achanta, A.S., Adusimilli, P.S., James, K.W., and Rhodes, C.T. "Hot melt coating:Water sorption behaviour of excipient films" Drug development and Industrial Pharmacy, 27(3), 241-250 (2001).

5) Martin, A. and Bustamante, P. Physical Pharmacy, Fourth Edition, Published by Lea \& Fbiger, Philadelphia (1993).

6) Labuza, T.P. " Sorption phenomena in foods", Food Technology, 22: 263-272 (1968.)

7) Zografi, G., Crastensen, J.T., Kontny, M., Attarchi F. "The sorption of water vapour by starch and the application of the Young And Nelson equation", J.Pharm. Pharmacol, 35: 455-458 (1983).

8) Tabibi, S.E. "Water vapor adsorption by compressible sugar and its effect on powder compressibility", Ph.D. Thesis, University of Maryland, USA (1982).

9) Tabibi, S.E. and Hollenbeck, R.G. "Interaction of water vapor and compressible sugar", International Journal of Pharmaceutics, 18: 169-183 (1984).

10) Khan, F. and Pilpel, N. "An investigation of moisture sorption in microcrystalline cellulose using sorption isotherms and dielectric response", Powder Technology, 50: 237-241(1987). 
Table1: Estimates of microrate constants for sorption $\left(\mathrm{k}_{1}\right)$ and desorption $\left(\mathrm{k}_{2}\right)$ processes assuming Langmuir behaviour for hydroxyprpyl methylcellulose film

\begin{tabular}{|c|c|c|c|c|c|c|}
\hline \multicolumn{7}{|c|}{ Sorption microrate constants $\left(\mathrm{k}_{1} \times 10^{5} \mathrm{in} / \mathrm{min}\right)$} \\
\hline & $\mathrm{T}=293 \mathrm{~K}$ & & $\mathrm{~T}=303 \mathrm{~K}$ & & $\mathrm{~T}=313 \mathrm{~K}$ & \\
\hline $\begin{array}{c}\text { Water } \\
\text { activity }\end{array}$ & $\begin{array}{c}\text { Mean } \\
(\mathrm{n}=3)\end{array}$ & $\mathrm{SD}$ & $\begin{array}{c}\text { Mean } \\
(\mathrm{n}=3)\end{array}$ & $\mathrm{SD}$ & $\begin{array}{c}\text { Mean } \\
(\mathrm{n}=3)\end{array}$ & $\mathrm{SD}$ \\
\hline 0.17 & 3.05 & 0.99 & 7.88 & 1.33 & 6.54 & 2.59 \\
\hline 0.34 & 2.91 & 1.01 & 7.57 & 1.15 & 6.05 & 2.98 \\
\hline 0.51 & 3.30 & 1.40 & 9.00 & 0.97 & 7.50 & 2.78 \\
\hline 0.68 & 3.91 & 1.61 & 11.1 & 1.19 & 9.32 & 2.71 \\
\hline 0.85 & 5.31 & 0.72 & 15.0 & 1.35 & 14.9 & 4.10 \\
\hline \multicolumn{7}{|c|}{ Desorption micro rate constant $\left(\mathrm{k}_{2} \mathrm{X} 10^{5}\right.$ in $\left.\mathrm{g} / \mathrm{min}\right)$} \\
\hline Water & $\mathrm{T}=293 \mathrm{~K}$ & \multicolumn{7}{|c|}{ Mean } & $\mathrm{T}=303 \mathrm{~K}$ & & $\mathrm{~T}=313 \mathrm{~K}$ & \\
\hline activity & $(\mathrm{n}=3)$ & $\begin{array}{c}\text { Mean } \\
(\mathrm{n}=3)\end{array}$ & $\mathrm{SD}$ & $\begin{array}{c}\text { Mean } \\
(\mathrm{n}=3)\end{array}$ & $\mathrm{SD}$ \\
\hline 0.17 & 3.51 & 1.61 & 8.09 & 0.98 & 7.89 & 3.01 \\
\hline 0.34 & 4.36 & 2.08 & 9.53 & 1.33 & 8.89 & 3.94 \\
\hline 0.51 & 5.00 & 1.70 & 10.7 & 0.89 & 10.5 & 3.77 \\
\hline 0.68 & 7.15 & 1.92 & 12.1 & 0.02 & 18.6 & 6.41 \\
\hline
\end{tabular}


Table2: Estimates of microrate constants for sorption $\left(\mathrm{k}_{1}\right)$ and desorption $\left(\mathrm{k}_{2}\right)$ processes assuming Langmuir behaviour for modified hydroxyprpyl methylcellulose film

\begin{tabular}{|c|c|c|c|c|c|c|}
\hline \multicolumn{7}{|c|}{ Sorption microrate constants $\left(\mathrm{k}_{1} \times 10^{5}\right.$ in $\left.\mathrm{g} / \mathrm{min}\right)$} \\
\hline $\begin{array}{c}\text { Water } \\
\text { activity }\end{array}$ & $\begin{array}{c}\mathrm{T}=293 \mathrm{~K} \\
\text { Mean } \\
(\mathrm{n}=3)\end{array}$ & $\mathrm{SD}$ & $\begin{array}{c}\mathrm{T}=303 \mathrm{~K} \\
(\mathrm{n}=3)\end{array}$ & $\mathrm{T}=313 \mathrm{~K}$ & $\mathrm{Mean}(\mathrm{n}=3)$ & $\mathrm{SD}$ \\
\hline 0.17 & 3.44 & 3.93 & 4.93 & 1.68 & 4.88 & 1.03 \\
\hline 0.34 & 3.38 & 3.66 & 4.87 & 1.69 & 4.48 & 1.41 \\
\hline 0.51 & 3.95 & 4.03 & 5.87 & 2.00 & 5.68 & 1.50 \\
\hline 0.68 & 4.15 & 4.15 & 7.19 & 2.31 & 6.81 & 1.66 \\
\hline 0.85 & 4.01 & 4.61 & 8.79 & 2.28 & 10.4 & 2.84 \\
\hline \multicolumn{7}{|c|}{ Desorption micro rate constant $\left(\mathrm{k}_{2} \mathrm{X} 10^{5}\right.$ in $\left.\mathrm{g} / \mathrm{min}\right)$} \\
\hline Water & $\mathrm{T}=293 \mathrm{~K}$ & $\mathrm{~T}$ & $\mathrm{~T}=303 \mathrm{~K}$ & & $\mathrm{~T}=313 \mathrm{~K}$ & \\
\hline Mean & SD & $\begin{array}{c}\text { Mean } \\
(\mathrm{n}=3)\end{array}$ & $\mathrm{SD}$ & $\begin{array}{c}\text { Mean } \\
(\mathrm{n}=3)\end{array}$ & $\mathrm{SD}$ \\
\hline 0.17 & 2.72 & 2.87 & 6.07 & 4.21 & 5.66 & 1.49 \\
\hline 0.34 & 3.51 & 3.38 & 7.38 & 3.46 & 7.44 & 1.68 \\
\hline 0.51 & 4.22 & 4.15 & 8.72 & 2.60 & 9.05 & 2.31 \\
\hline 0.68 & 4.88 & 5.14 & 10.1 & 2.53 & 14.7 & 4.24 \\
\hline
\end{tabular}


Table 3: Estimates of microrate constants for sorption $\left(\mathrm{k}_{1}\right)$ and desorption $\left(\mathrm{k}_{2}\right)$ processes assuming Langmuir behaviour for microcrystaline cellulose film

\begin{tabular}{|c|c|c|c|c|c|c|}
\hline \multicolumn{7}{|c|}{ Sorption microrate constants $\left(\mathrm{k}_{1} \times 10^{5} \mathrm{in} \mathrm{g} / \mathrm{min}\right)$} \\
\hline & $\mathrm{T}=293 \mathrm{~K}$ & & $\mathrm{~T}=303 \mathrm{~K}$ & & $\mathrm{~T}=313 \mathrm{~K}$ & \\
\hline $\begin{array}{l}\text { Water } \\
\text { activity }\end{array}$ & $\begin{array}{l}\text { Mean } \\
(n=3)\end{array}$ & SD & Mean $(n=3)$ & SD & Mean $(n=3)$ & $\mathrm{SD}$ \\
\hline 0.17 & 1.75 & 1.11 & 2.59 & 0.72 & 3.32 & 1.23 \\
\hline 0.34 & 2.12 & 1.07 & 3.03 & 0.65 & 4.13 & 1.26 \\
\hline 0.51 & 3.62 & 1.52 & 5.23 & 1.24 & 7.43 & 2.27 \\
\hline 0.68 & 6.61 & 3.24 & 9.28 & 1.96 & 12.2 & 3.50 \\
\hline 0.85 & 13.3 & 11.5 & 18.2 & 7.63 & 21.7 & 5.67 \\
\hline \multicolumn{7}{|c|}{ Desorption micro rate constant $\left(\mathrm{k}_{2} \times 10^{5}\right.$ in $\left.\mathrm{g} / \mathrm{min}\right)$} \\
\hline & $\mathrm{T}=293 \mathrm{~K}$ & & $\mathrm{~T}=303 \mathrm{~K}$ & & $\mathrm{~T}=313 \mathrm{~K}$ & \\
\hline $\begin{array}{l}\text { Water } \\
\text { activity }\end{array}$ & $\begin{array}{l}\text { Mean } \\
(n=3)\end{array}$ & $\mathrm{SD}$ & $\begin{array}{l}\text { Mean } \\
(n=3)\end{array}$ & SD & $\begin{array}{l}\text { Mean } \\
(n=3)\end{array}$ & $\mathrm{SD}$ \\
\hline 0.17 & 2.37 & 0.45 & 2.82 & 2.59 & 4.38 & 1.21 \\
\hline 0.34 & 4.48 & 0.82 & 5.71 & 1.36 & 7.86 & 2.68 \\
\hline 0.51 & 7.19 & 1.06 & 10.2 & 0.48 & 17.6 & 3.28 \\
\hline 0.68 & 11.8 & 3.13 & 18.5 & 0.41 & 26.6 & 3.55 \\
\hline
\end{tabular}


Table 4: Results of BET model fits for films of a) hydroxypropyl methylcellulose, b) modified hydroxypropyl methylcellulose, and c) microcrystaline cellulose.

BET results are valid for $0.17 \leq \mathrm{a}_{\mathrm{w}} \leq 0.51$

\begin{tabular}{|l|c|c|c|}
\hline a) & & \multicolumn{2}{|c|}{} \\
\hline Temp(K) & $\mathrm{C}_{\text {BET }}$ & $\mathrm{V}_{\mathrm{m}}(\mathrm{g}$ of water/g of film & $\mathrm{H}_{\mathrm{s}}(\mathrm{J} / \mathrm{mole})$ \\
\hline 293 & 3.00 & 0.04 & 2635.71 \\
\hline 303 & 2.94 & 0.03 & 2712.10 \\
\hline 313 & 2.86 & 0.03 & 2729.40 \\
\hline b) & 0.03 & 3065.98 \\
\hline 293 & 3.53 & 0.03 & 2972.16 \\
\hline 303 & 3.28 & 0.03 & 3249.92 \\
\hline 313 & 3.49 & 0.03 & 2415.98 \\
\hline c) & \multicolumn{3}{|c|}{} \\
\hline 293 & 3.07 & 0.05 & 1981.06 \\
\hline 303 & 2.60 & 0.03 & 3655.01 \\
\hline 313 & 4.08 & & \\
\hline
\end{tabular}


Table 5: Results of GAB model fits for films of a) hydroxypropyl methylcellulose, b) modified hydroxypropyl methylcellulose, and c)microcrystaline cellulose at varying temperatures

\begin{tabular}{|c|c|c|c|}
\hline \multicolumn{4}{|l|}{ a) } \\
\hline $\mathrm{T}(\mathrm{K})$ & K & $\mathrm{C}_{\mathrm{GAB}}$ & $\begin{array}{l}\mathrm{V}_{\mathrm{m}}(\mathrm{g} \text { of water } / \mathrm{g} \\
\text { of film }\end{array}$ \\
\hline 293 & 0.87 & 2.28 & 0.03 \\
\hline 303 & 0.89 & 2.48 & 0.03 \\
\hline 313 & 0.93 & 2.68 & 0.04 \\
\hline \multicolumn{4}{|l|}{ b) } \\
\hline 293 & 0.91 & 3.11 & 0.04 \\
\hline 303 & 0.89 & 2.86 & 0.03 \\
\hline 313 & 0.90 & 3.16 & 0.03 \\
\hline \multicolumn{4}{|l|}{ c) } \\
\hline 293 & 1.01 & 2.67 & 0.03 \\
\hline 303 & 0.90 & 2.25 & 0.03 \\
\hline 313 & 1.07 & 2.28 & 0.03 \\
\hline
\end{tabular}


Table 6: Estimates of Young and Nelson model parameters A, B and E used to describe hysterisis in sorption data for films of a) hydroxypropyl methylcellulose,

b) modified hydroxypropyl methylcellulose, and c) microcrystaline cellulose

\begin{tabular}{|c|c|c|c|}
\hline \multicolumn{4}{|l|}{ a) } \\
\hline $\mathrm{T}(\mathrm{K})$ & A & B & $\mathrm{E}$ \\
\hline 293 & 0.03 & 0.04 & 0.77 \\
\hline 303 & 0.04 & 0.07 & 1.03 \\
\hline 313 & 0.04 & 0.03 & 0.77 \\
\hline \multicolumn{4}{|l|}{ b) } \\
\hline 293 & 0.03 & 0.07 & 0.89 \\
\hline 303 & 0.03 & 0.04 & 0.71 \\
\hline 313 & 0.04 & 0.02 & 0.72 \\
\hline \multicolumn{4}{|l|}{ c) } \\
\hline 293 & 0.04 & 0.11 & 2.44 \\
\hline 303 & 0.07 & 0.04 & 2.11 \\
\hline 313 & 0.16 & 0.5 & 14.5 \\
\hline
\end{tabular}


Figure1: Schematic representation of the dynamic vapor sorption technique apparatus

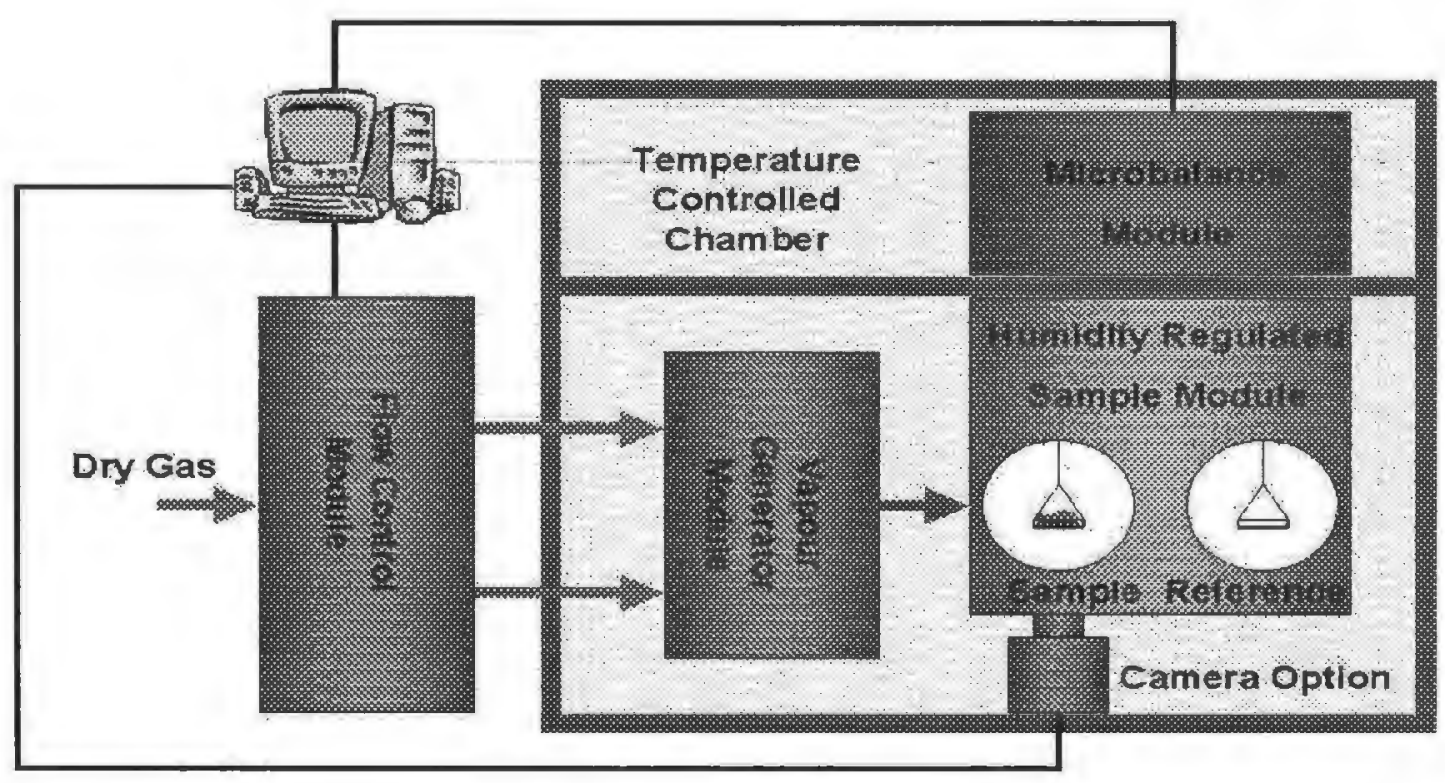


Figure 2: Sorption isotherms for hydroxypropyl methylcellulose (HPMC) film. Values of equilibrium moisture content $(V)$ are mean of $n=3$

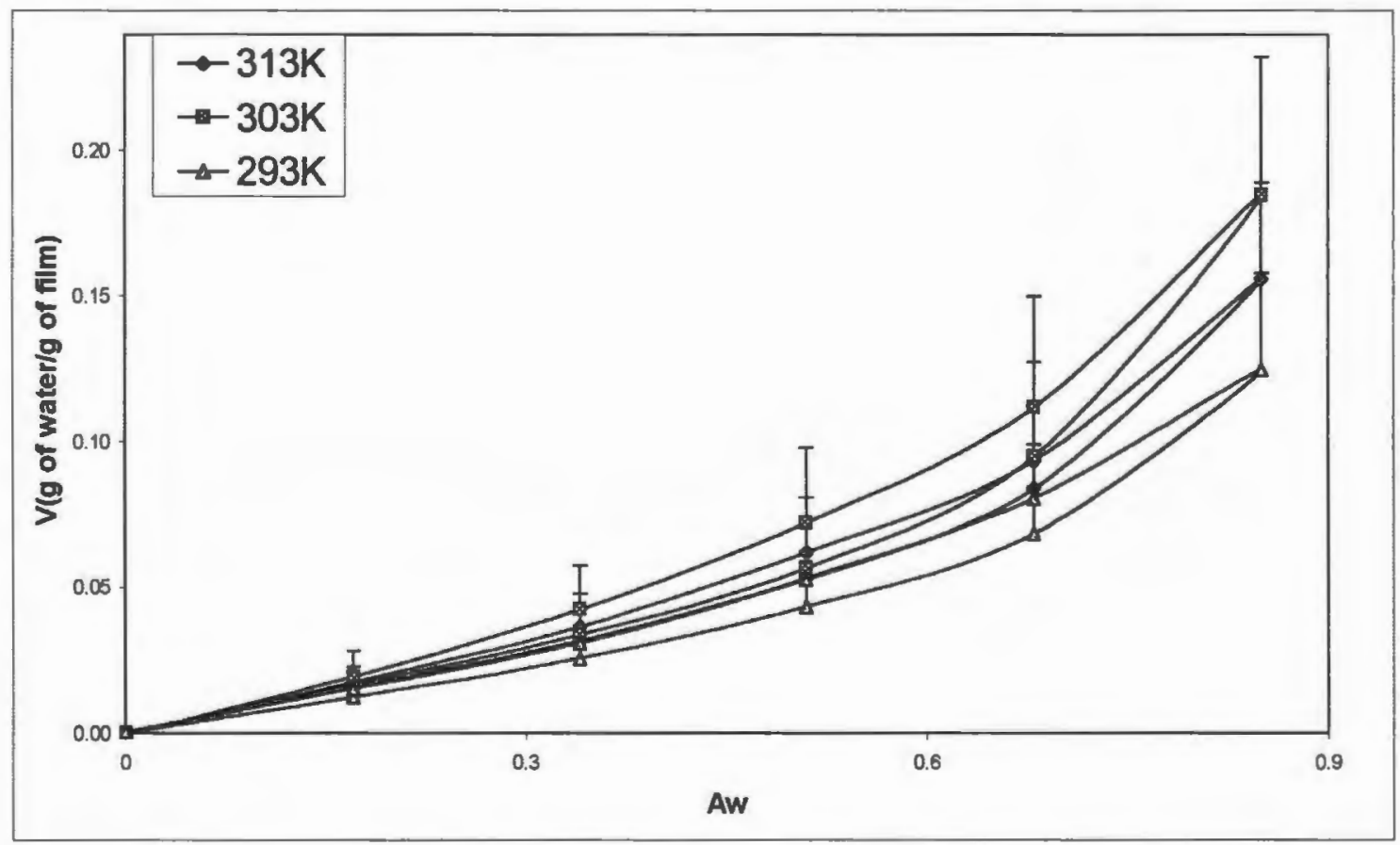


Figure 3: Sorption isotherms for modified hydroxypropyl methylcellulose films. Values of equilibrium moisture content $(V)$ are mean of $n=3$

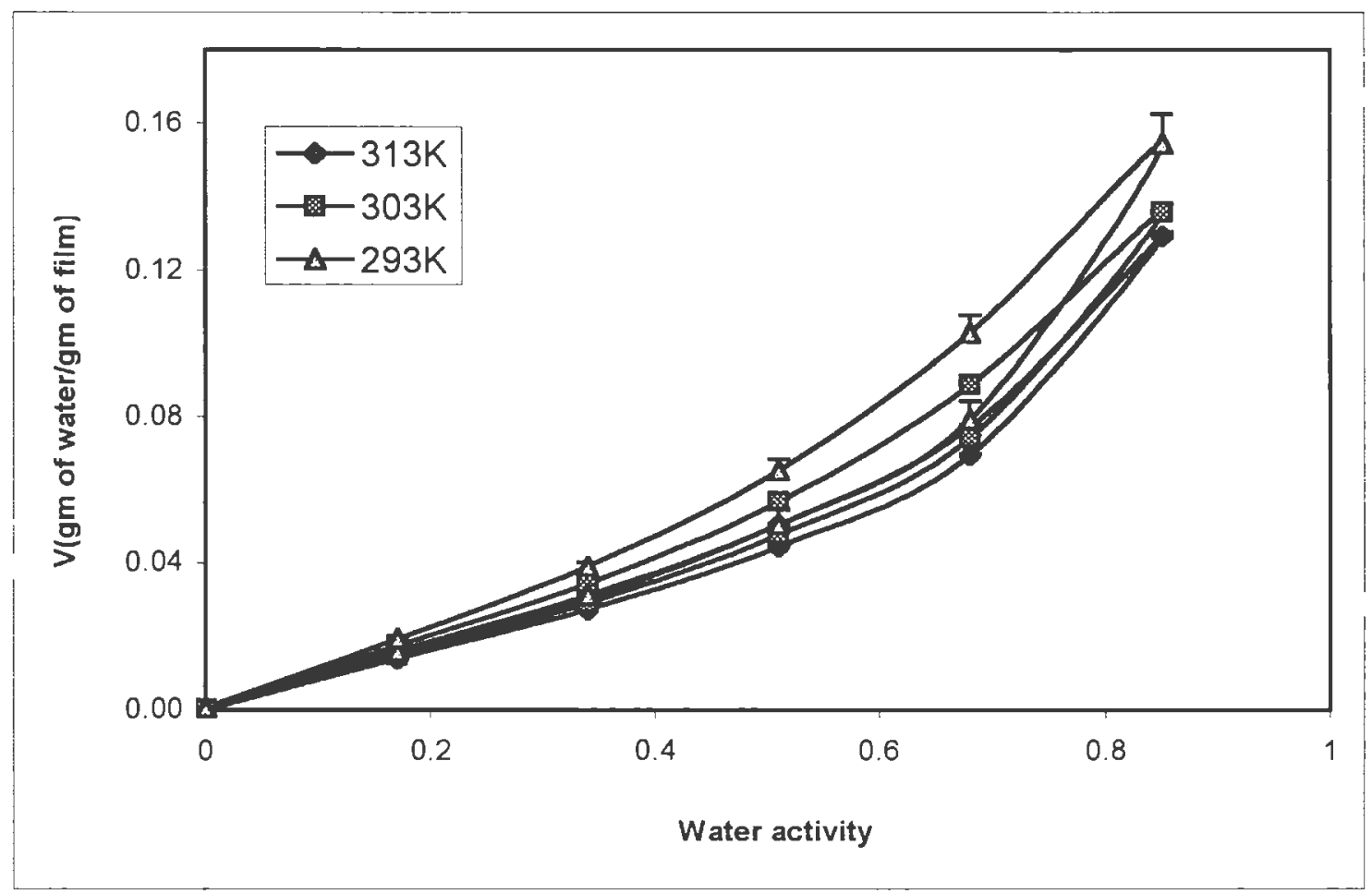


Figure 4: Sorption isotherms for microcrystaline cellulose (MCC) films.

Values of equilibrium moisture content $(V)$ are mean of $n=3$

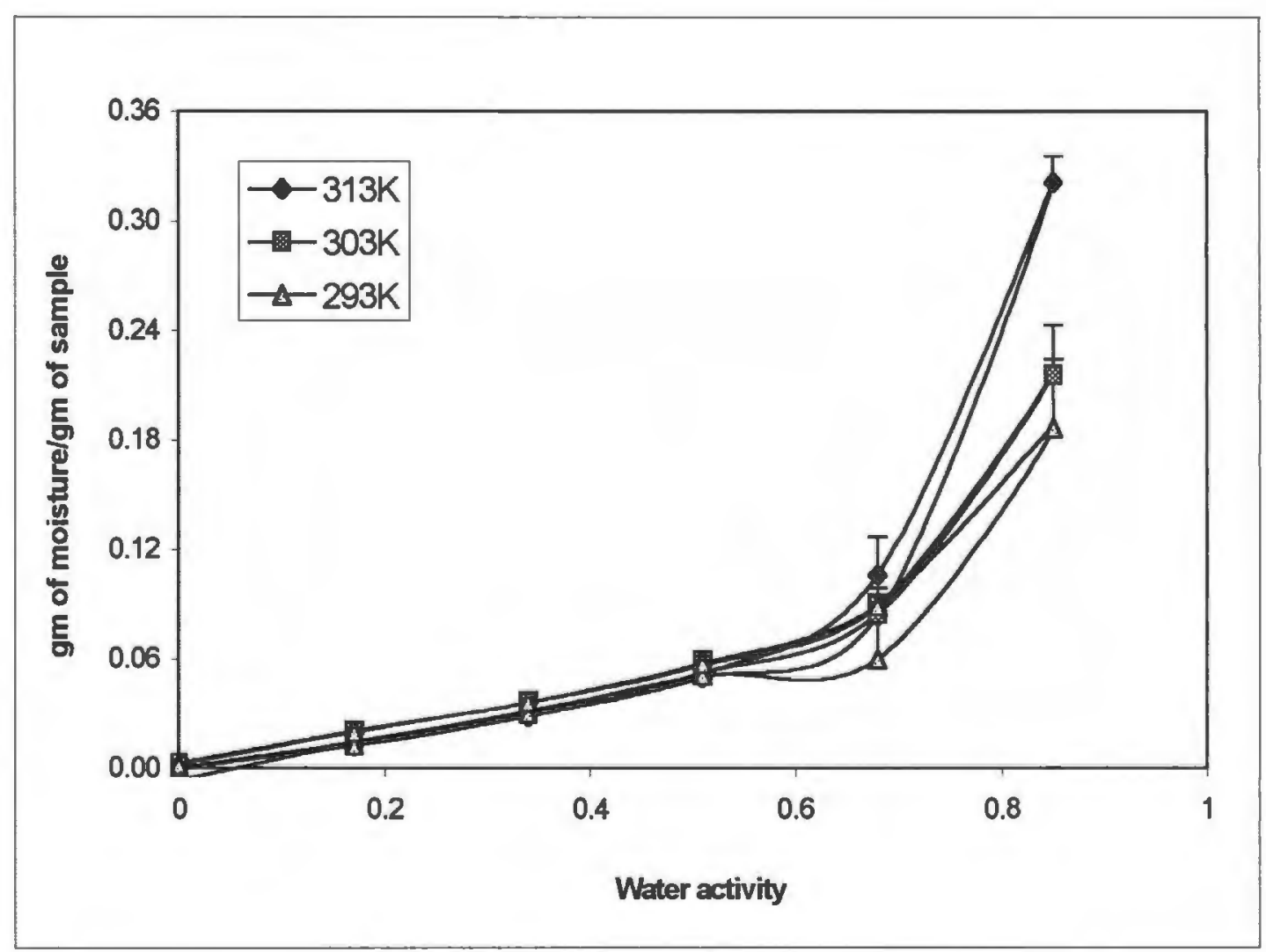


Figure 5:Fit of sorption data using GAB model for hydroxypropyl methylcellulose $(\mathrm{HPMC})$ at $\mathrm{T}=303 \mathrm{~K}, \bullet$ indicates actual data and —represents the fitted data obtained by nonlinear regression $(n=3)$

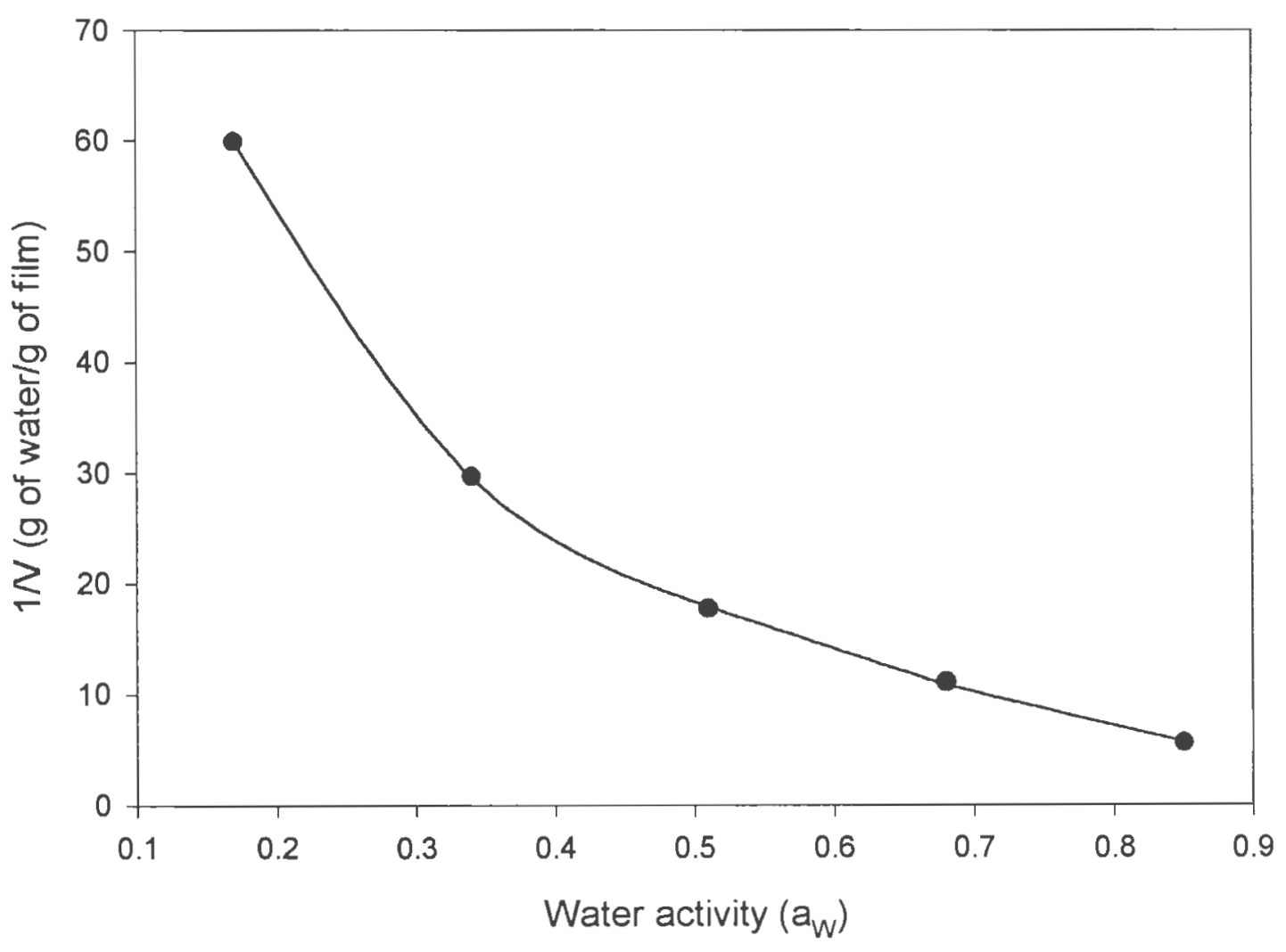


Figure6: Relative partial molal free energy $\left(\Delta \mathrm{G}_{2}\right.$ in $\left.\mathrm{KJ} / \mathrm{mol}\right)$ of adsorbed water on HPMC

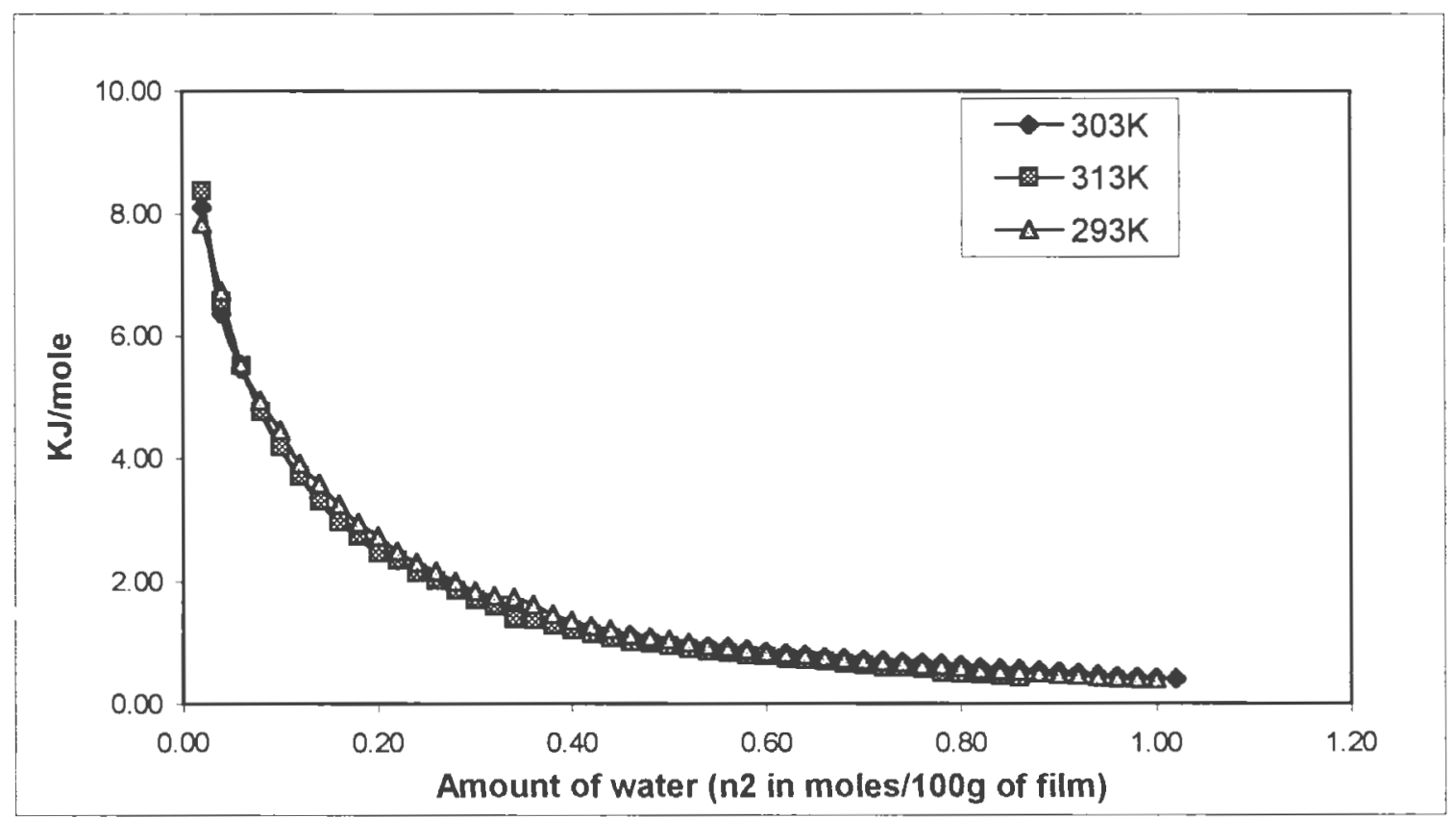


Figure 7:Relative partial molal free energy $\left(\Delta \mathrm{G}_{2}\right.$ in $\left.\mathrm{KJ} / \mathrm{mol}\right)$ of adsorbed water on modified HPMC .

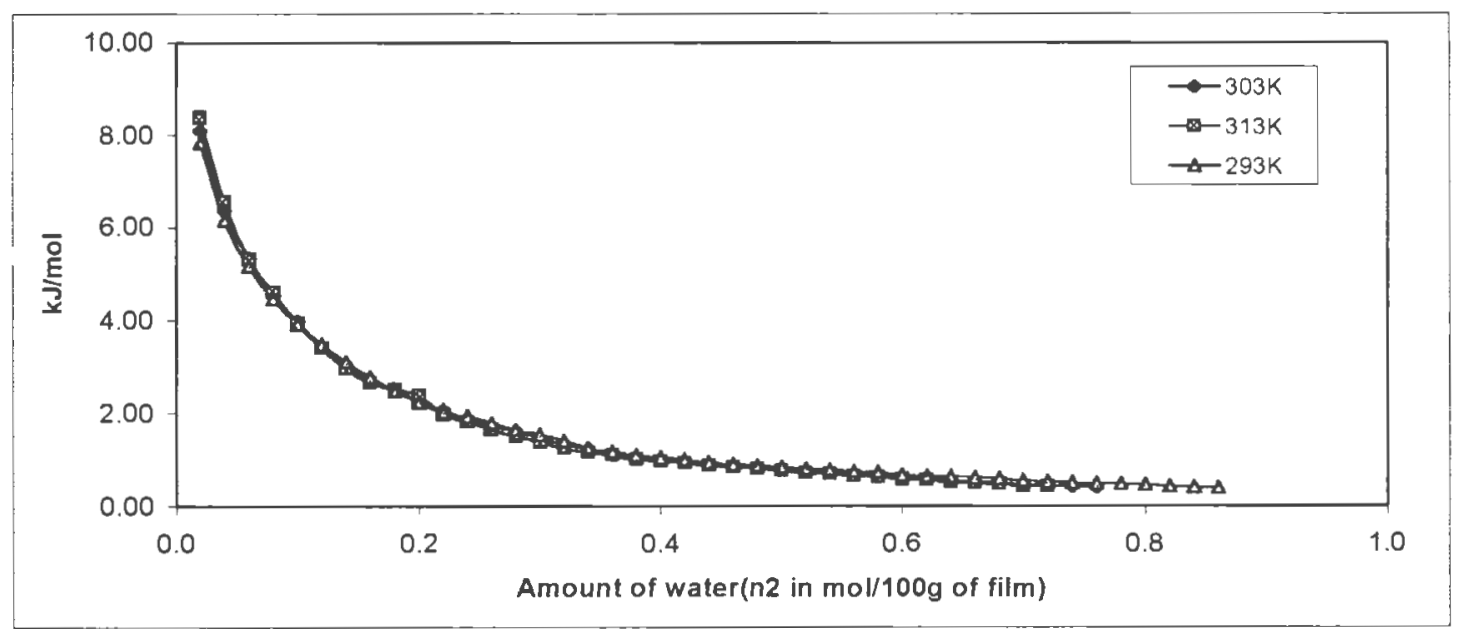


Figure 8: Relative partial molal free energy $\left(\Delta \mathrm{G}_{2}\right.$ in $\left.\mathrm{KJ} / \mathrm{mol}\right)$ of adsorbed water on micro crystaline cellulose .

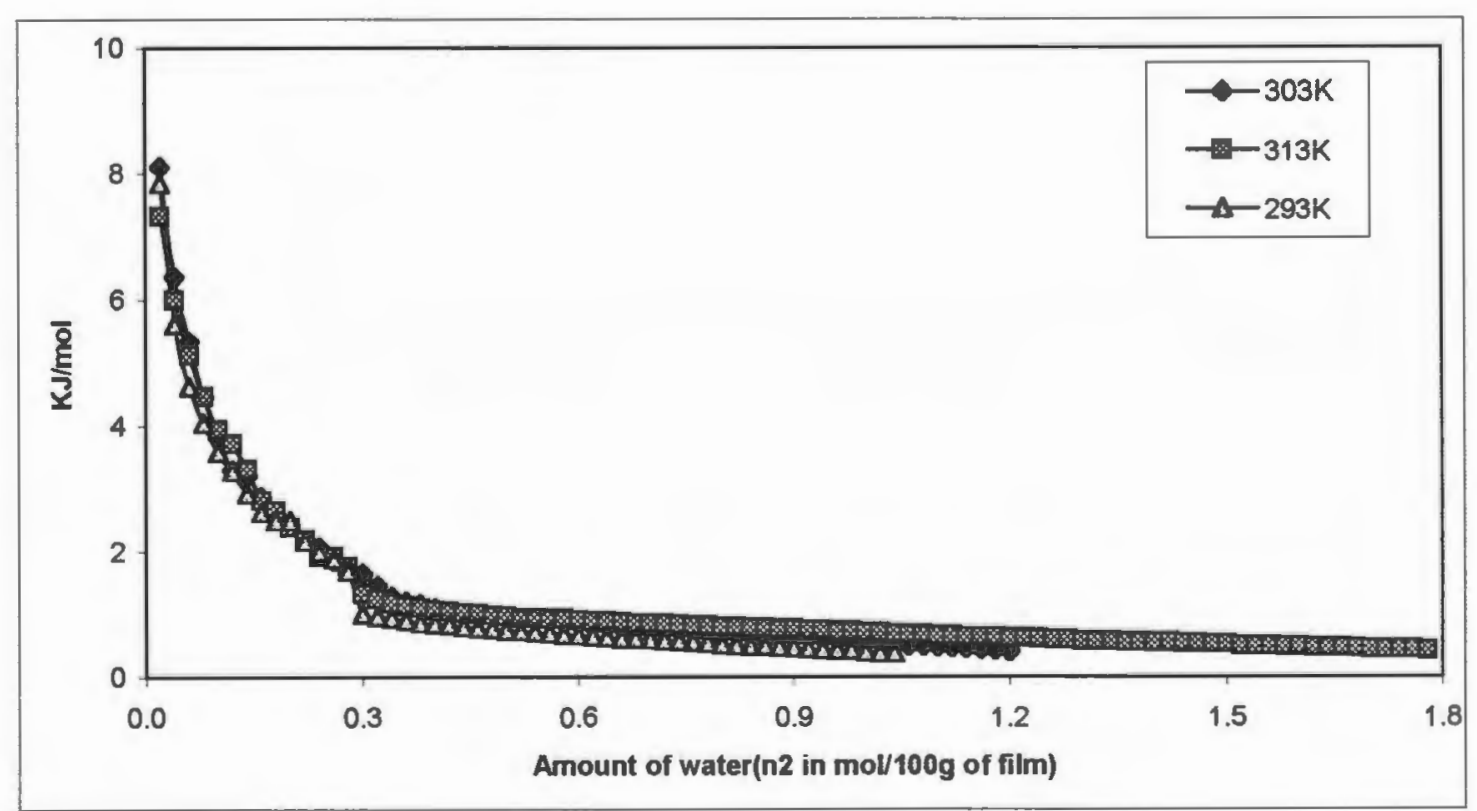


Figure 9: Integral free energy of adsorption $(\Delta \mathrm{G})$ and weighted relative partial molal free enegies of excipients film $\left(n_{1} \Delta G_{1}\right)$ and water $\left(n_{2} \Delta G_{2}\right)$ for water-Hpmc film at 303 $\mathrm{k}$

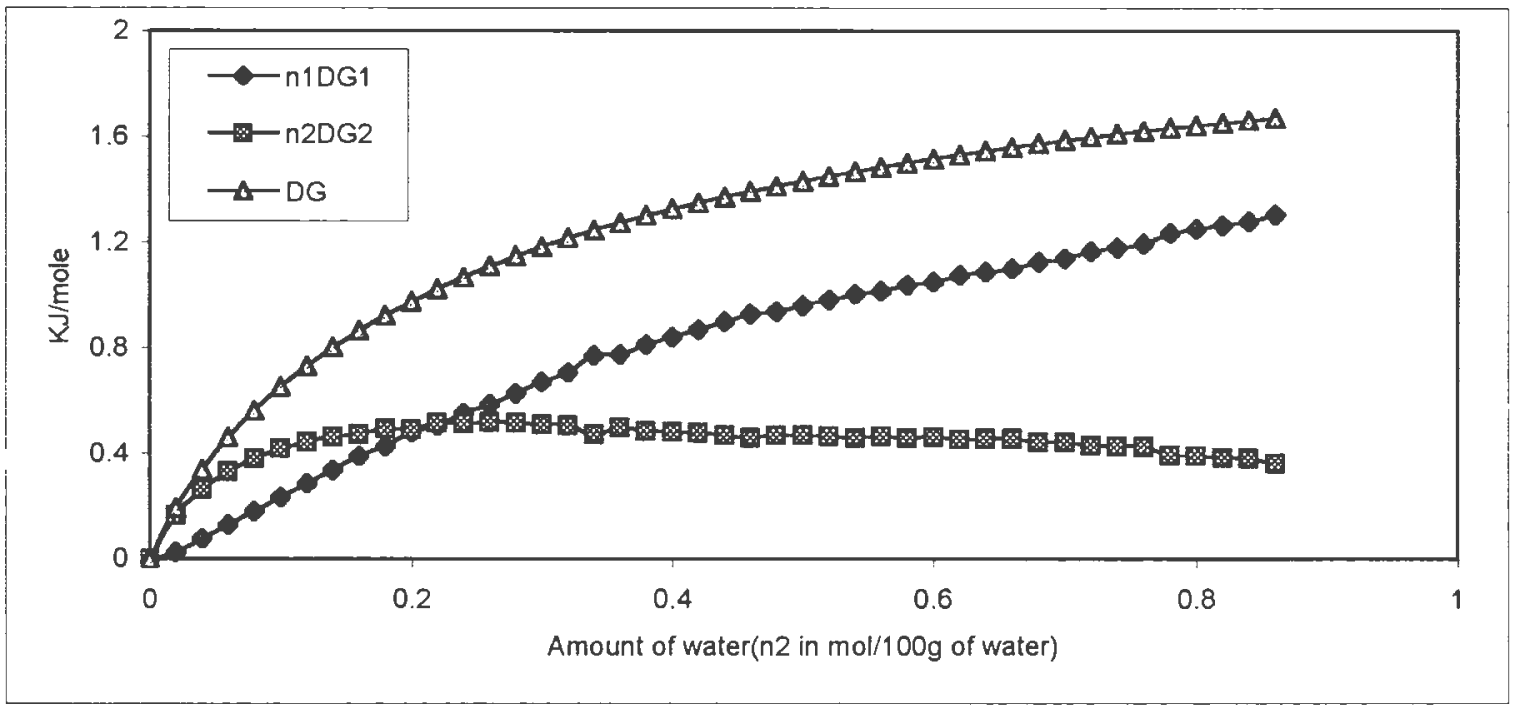


Figure 10: Integral free energy of adsorption $(\Delta \mathrm{G})$ and weighted relative partial molal free enegies of excipients film $\left(n_{1} \Delta G_{1}\right)$ and water $\left(n_{2} \Delta G_{2}\right)$ for water- modified Hpmc film at $303 \mathrm{~K}$

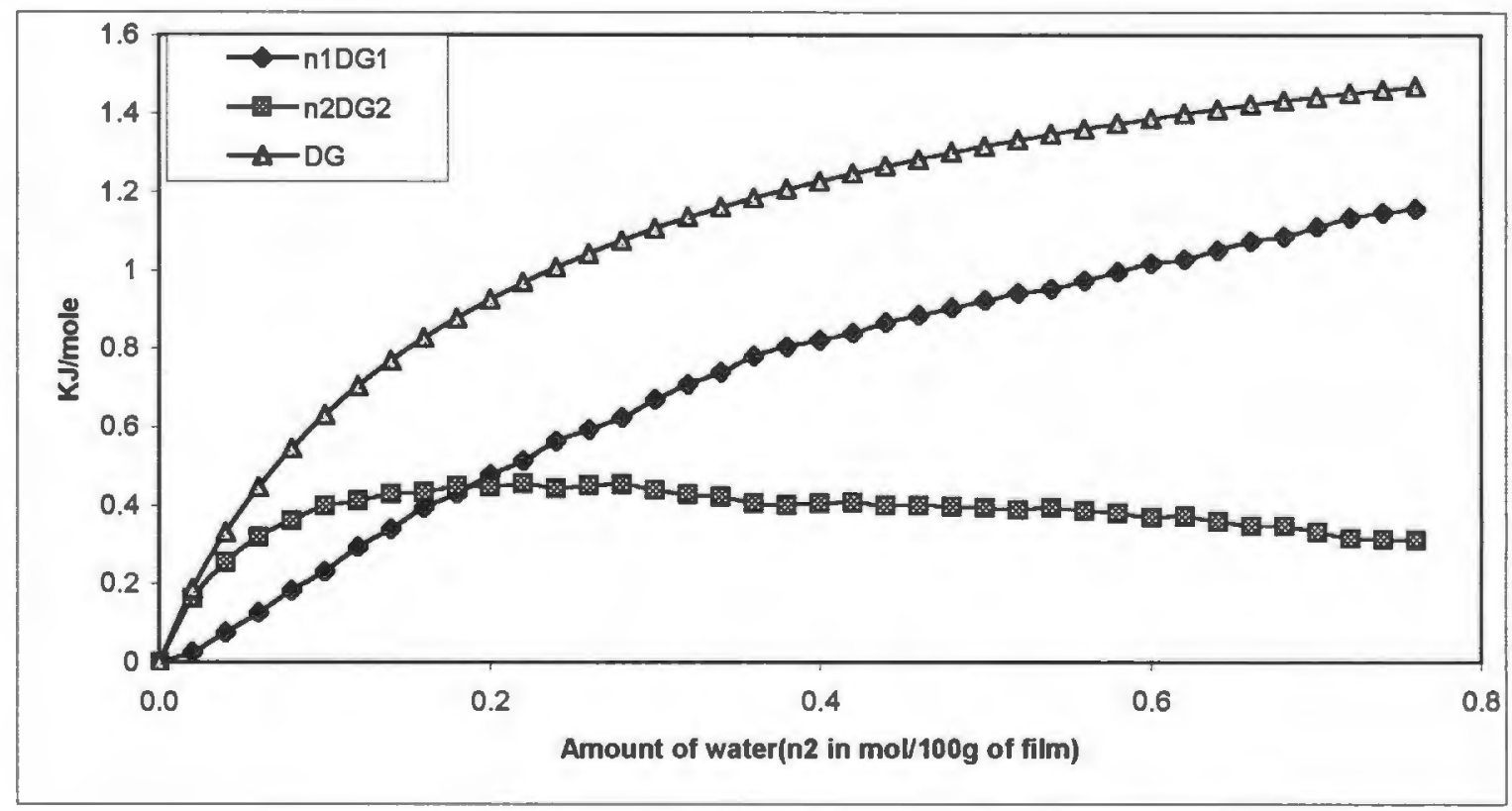


Figure 11: Integral free energy of adsorption $(\Delta G)$ and weighted relative partial molal free enegies of excipients film $\left(n_{1} \Delta G_{1}\right)$ and water $\left(n_{2} \Delta G_{2}\right)$ for watermicrocrystaline cellulose film at $303 \mathrm{k}$

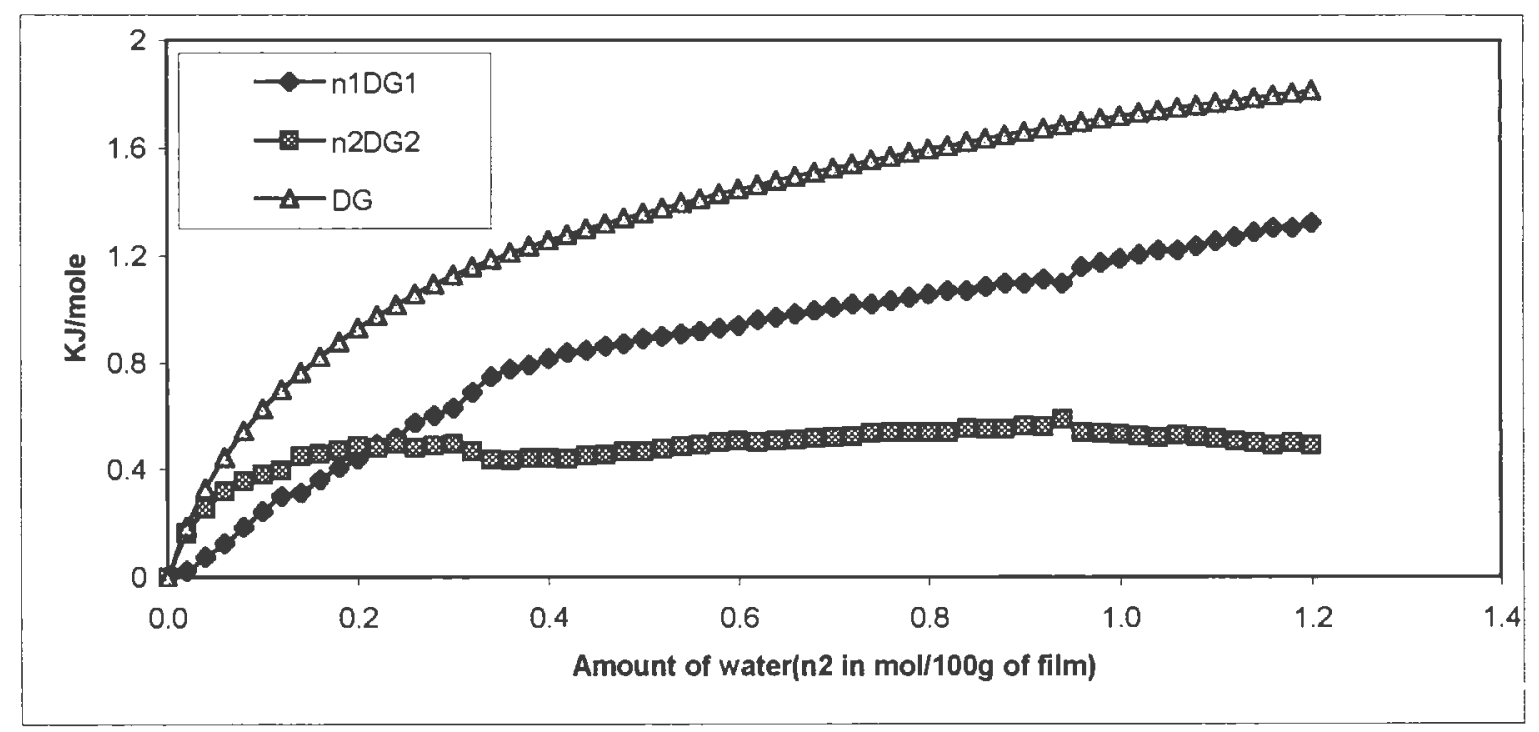


Figure 12: Relative partial molal enthalpy $\left(\Delta \mathrm{H}_{2}\right)$ of adsorbed water on HPMC film

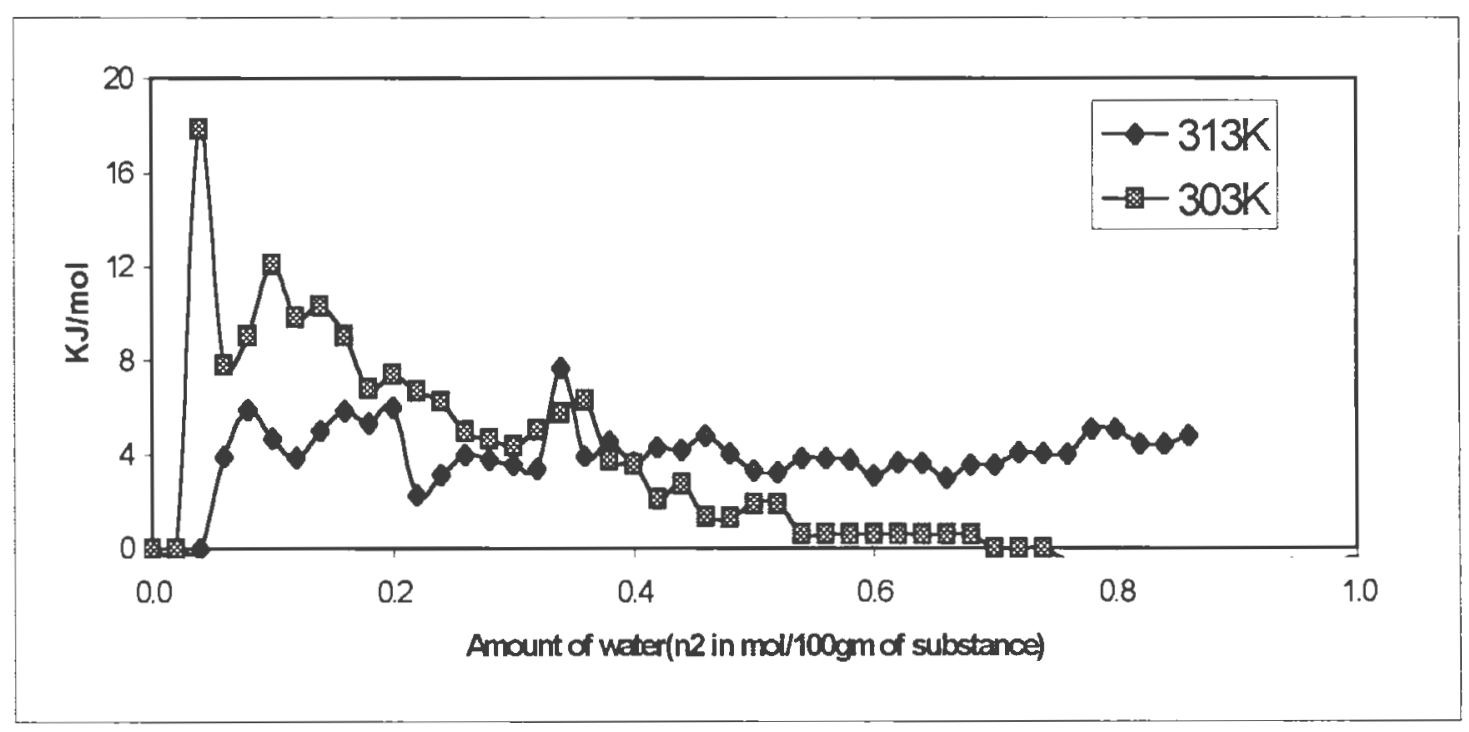


Figure 13: Relative partial molal enthalpy $\left(\Delta \mathrm{H}_{2}\right)$ of adsorbed water on modified HPMC film

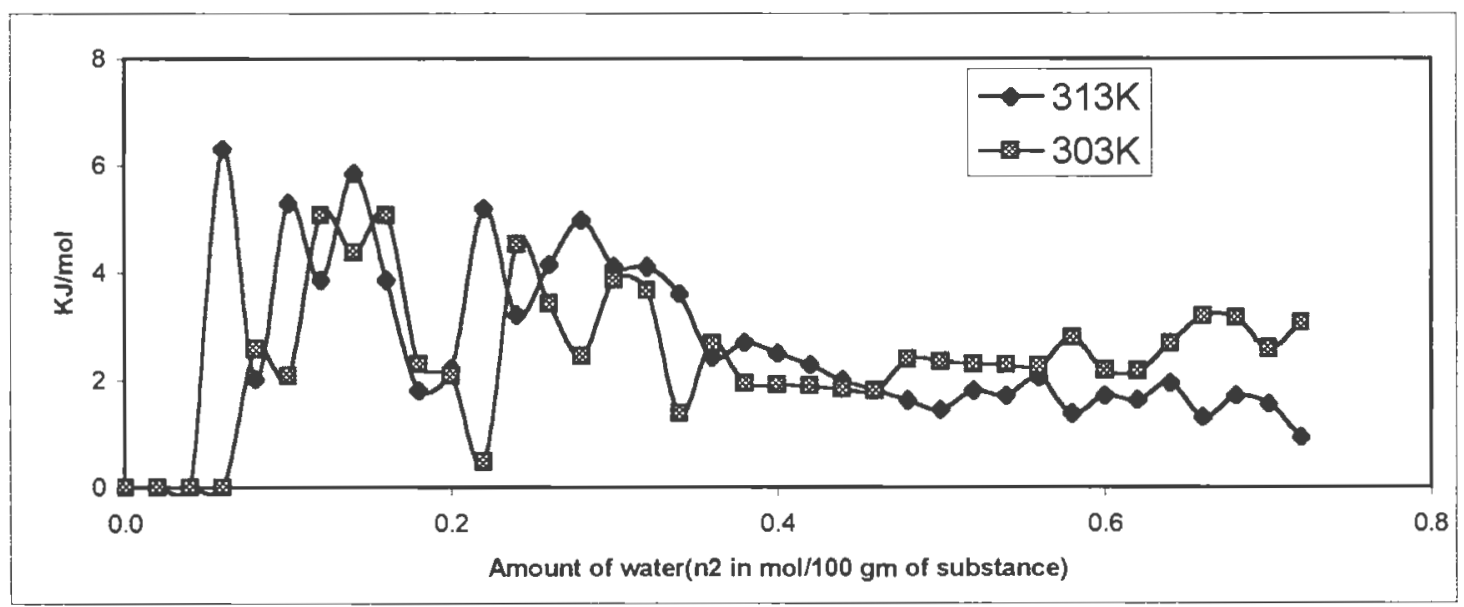


Figure 14: Relative partial molal enthalpy $\left(\Delta \mathrm{H}_{2}\right)$ of adsorbed water on microcrystaline cellulose film

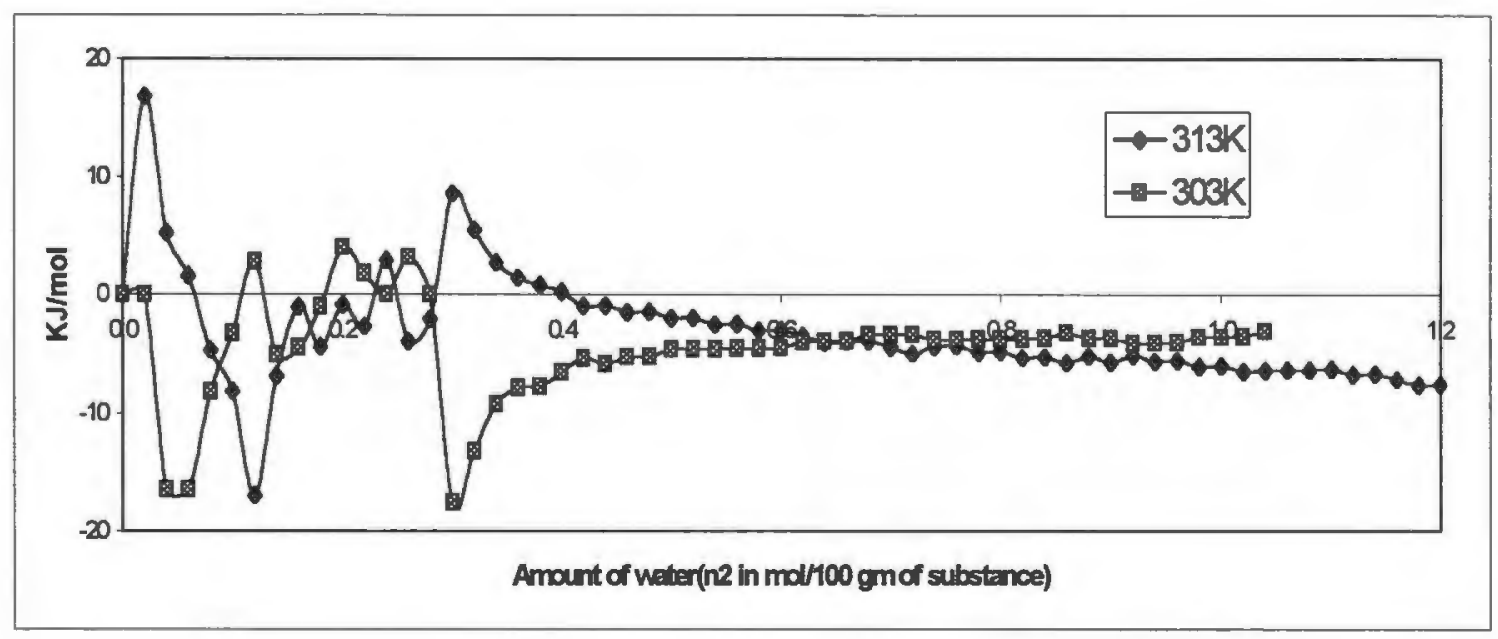


Figure 15: Integral enthalpy of adsorption $(\Delta \mathrm{H})$ and weighted relative partial molal enthalpies of excipients film $\left(\mathrm{n}_{1} \Delta \mathrm{H}_{1}\right)$ and water $\left(\mathrm{n}_{2} \Delta \mathrm{h}_{2}\right)$ for water-Hpmc film at $303 \mathrm{k}$

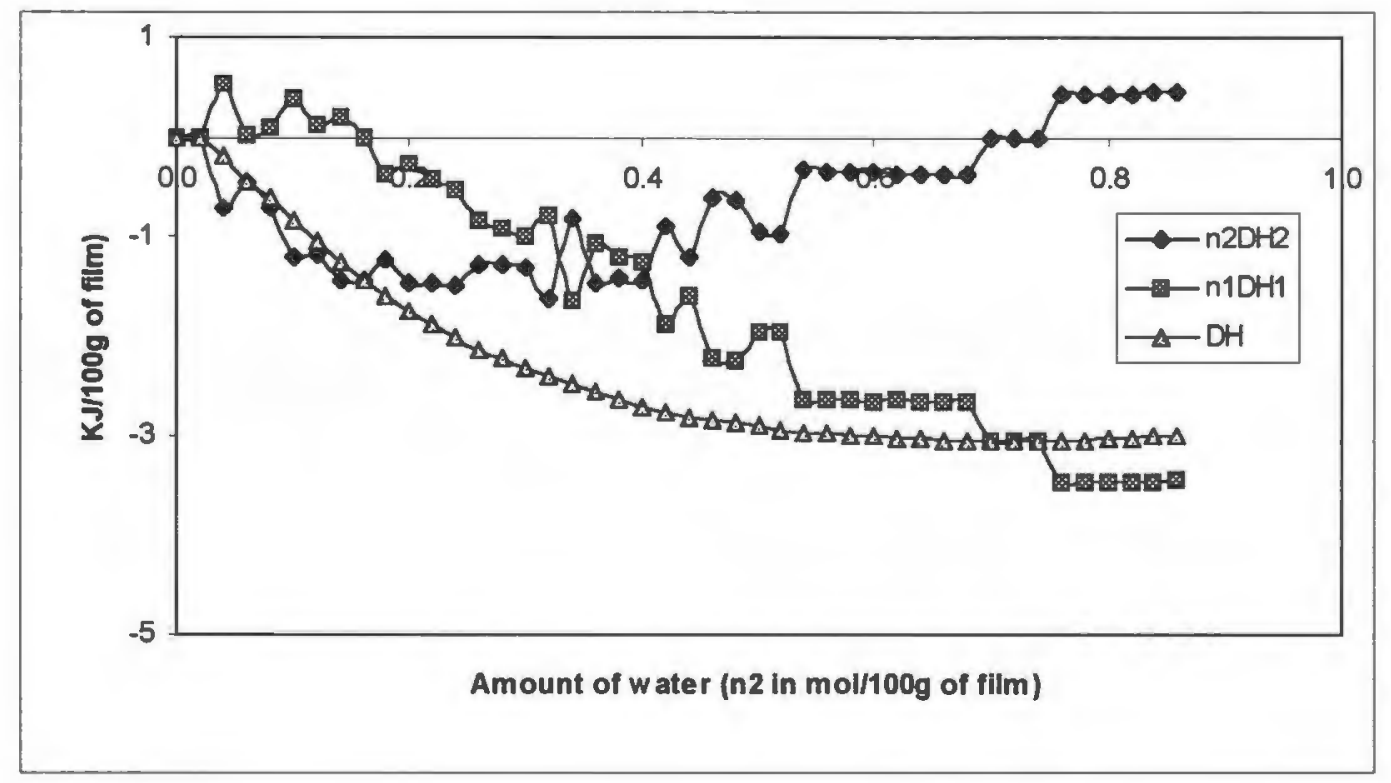


Figure 16: Integral enthalpy of adsorption $(\Delta \mathrm{H})$ and weighted relative partial molal enthalpies of excipients film $\left(\mathrm{n}_{1} \Delta \mathrm{H}_{1}\right)$ and water $\left(\mathrm{n}_{2} \Delta \mathrm{H}_{2}\right)$ for water-modified HPMC film at $303 \mathrm{k}$

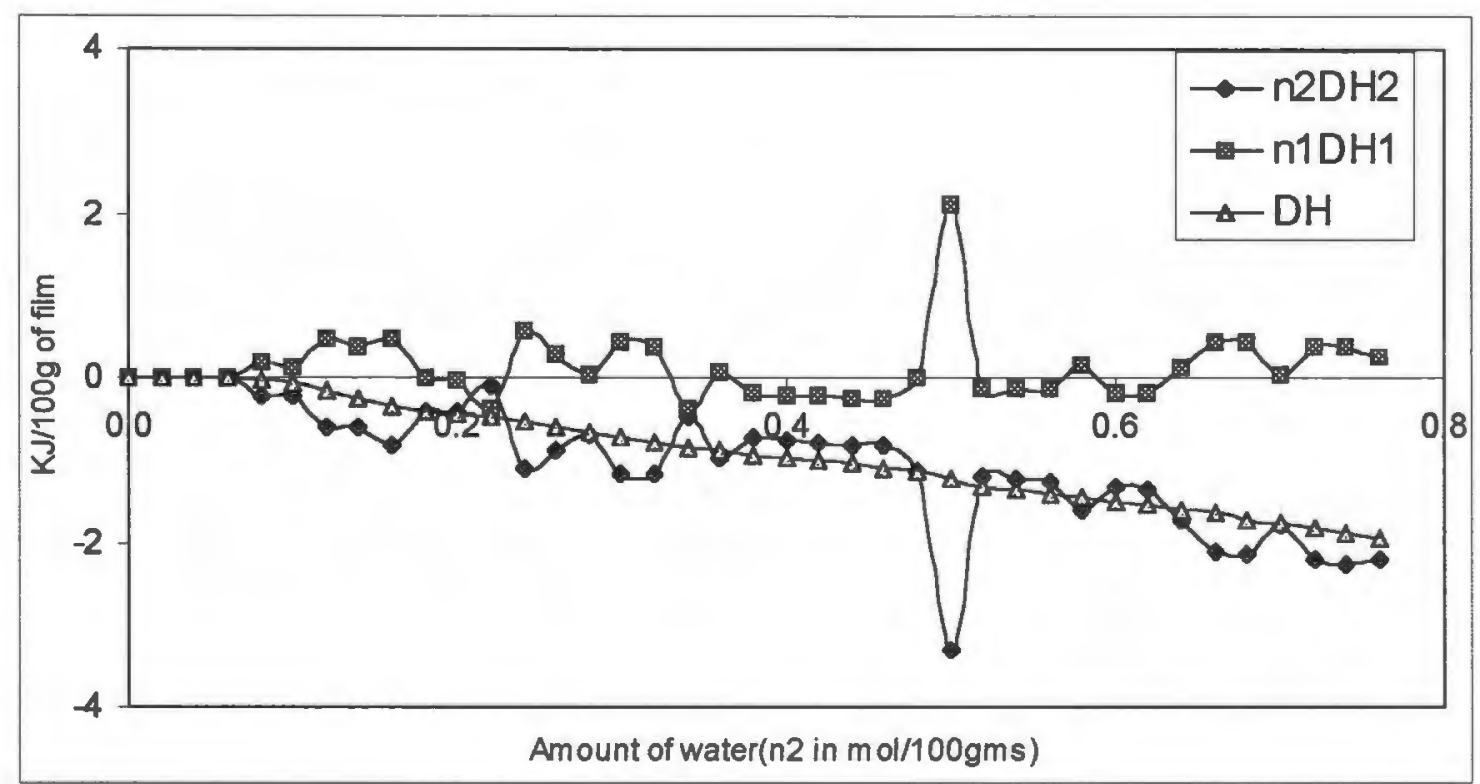


Figure 17: Integral enthalpy of adsorption $(\Delta \mathrm{H})$ and weighted relative partial molal enthalpies of excipients film $\left(\mathrm{n}_{1} \Delta \mathrm{H}_{1}\right)$ and water $\left(\mathrm{n}_{2} \Delta \mathrm{H}_{2}\right)$ for water-MCC film at $303 \mathrm{k}$

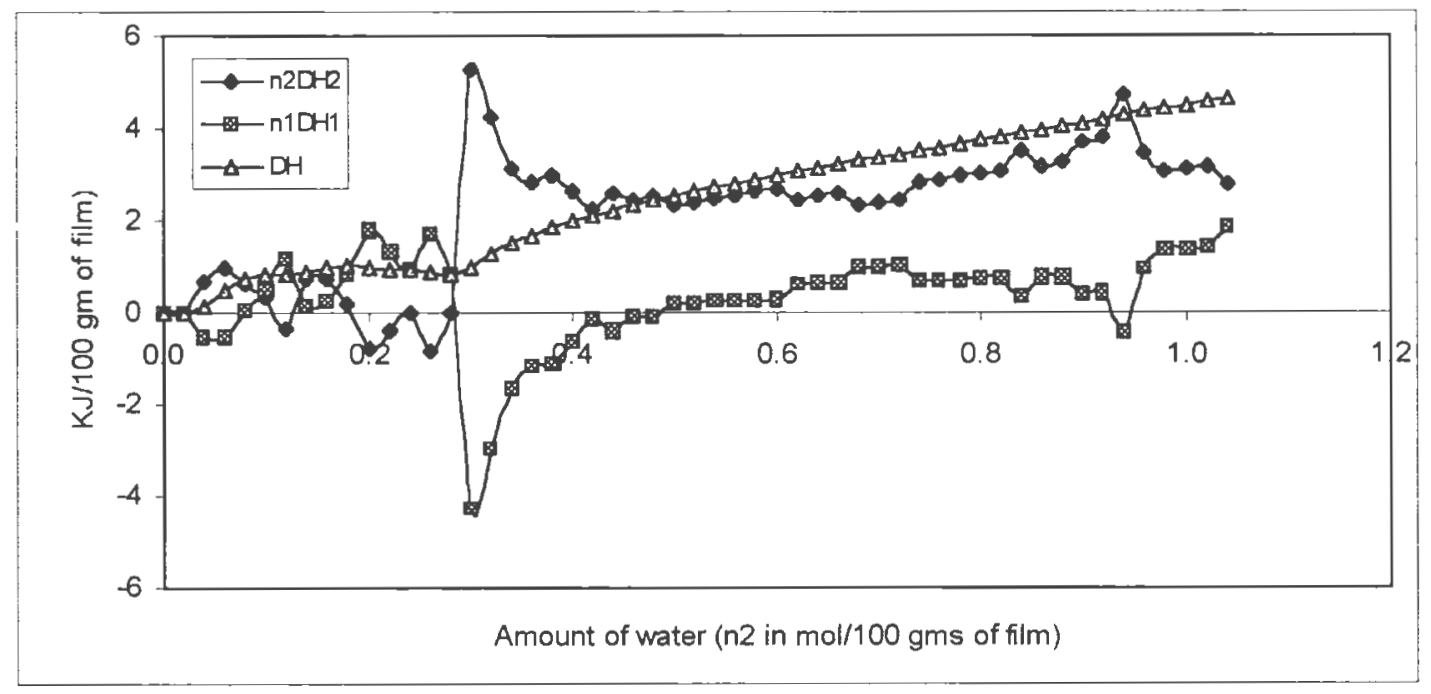


Figure 18: Relative partial molal entropy $\left(\Delta \mathrm{S}_{2}\right)$ of absorbed water on HPMC film

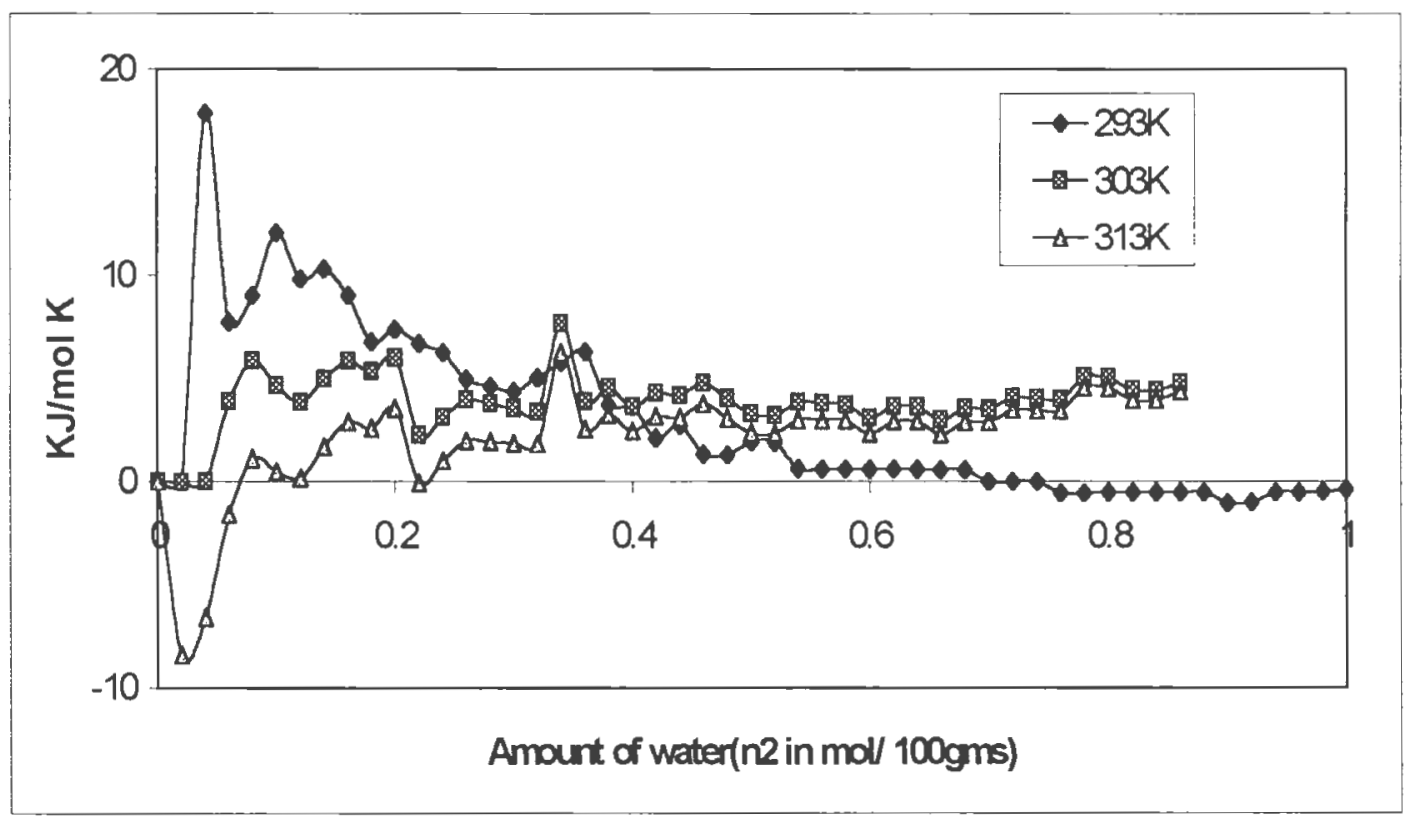


Figure 19: Relative partial molal entropy $\left(\Delta \mathbf{S}_{2}\right)$ of absorbed water on modified HPMC film

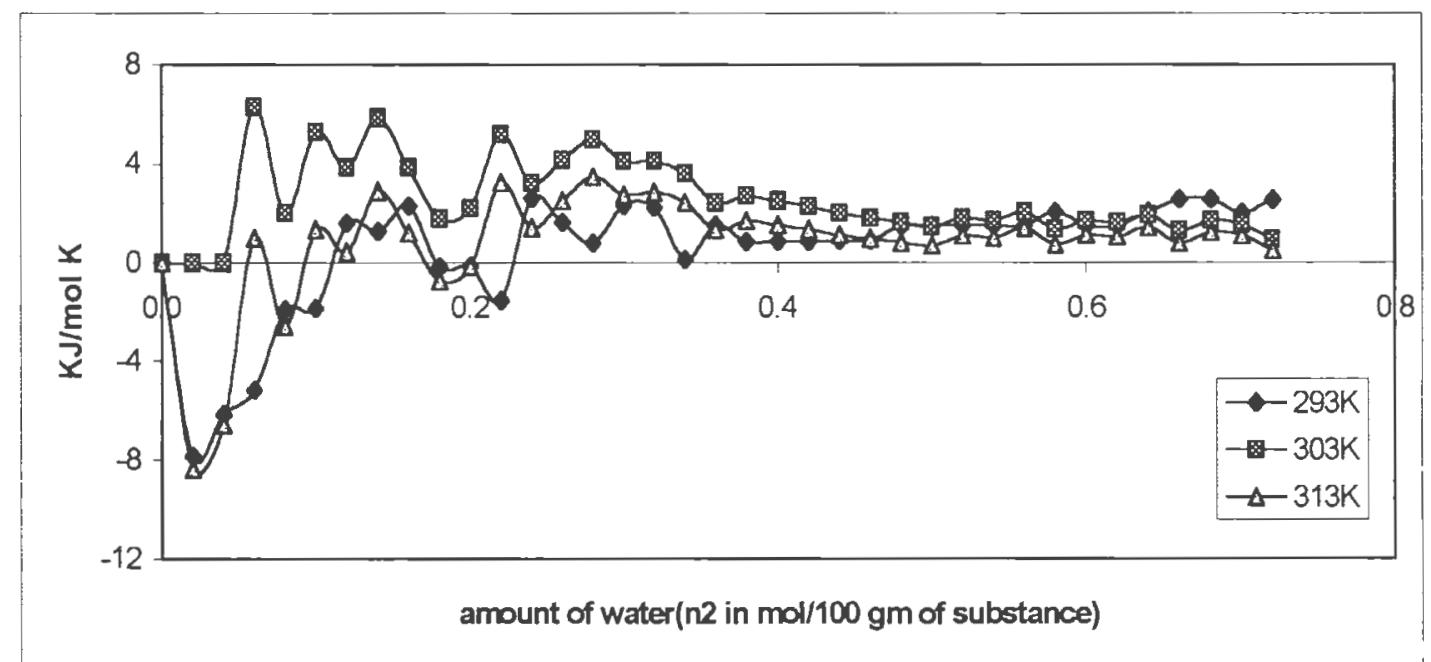


Figure 20: Relative partial molal entropy $\left(\Delta \mathrm{S}_{2}\right)$ of absorbed water on microcrystaline cellulose film

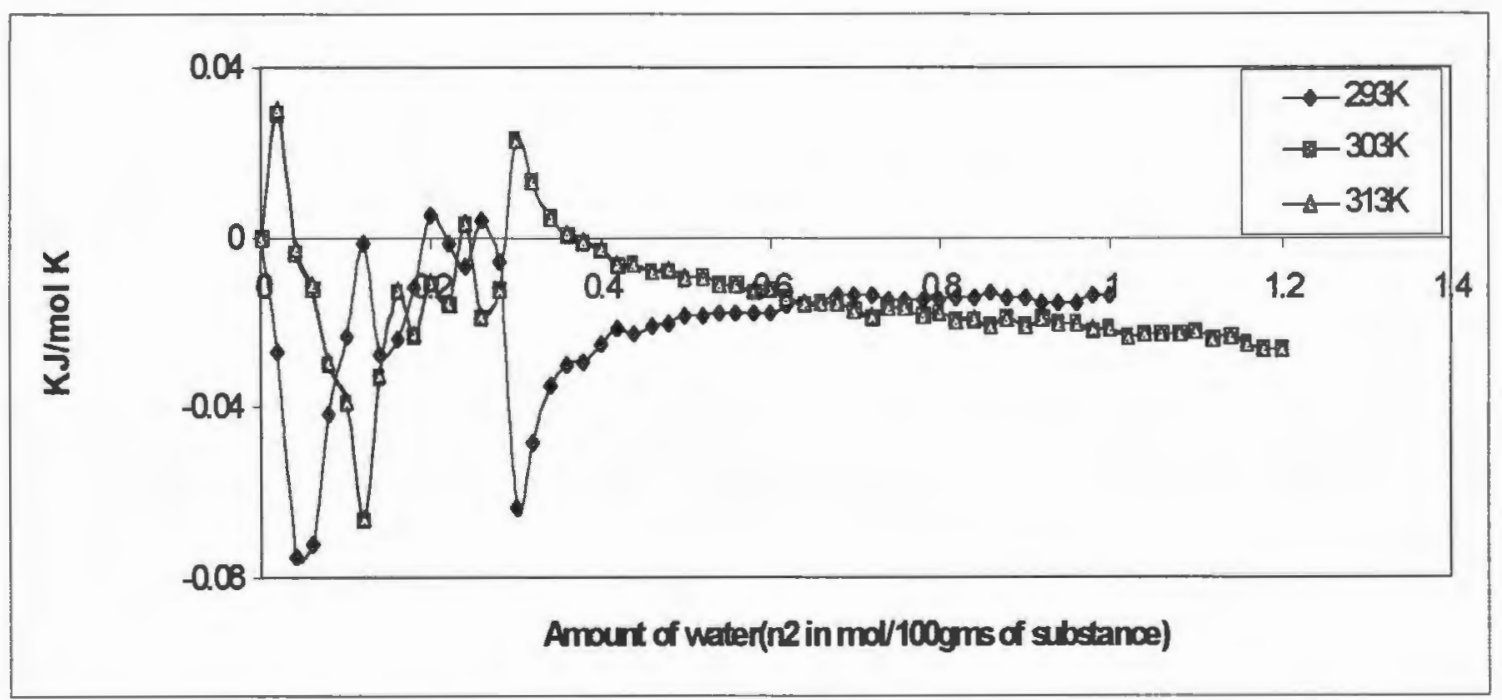




\section{SECTION III}

\section{APPENDIX A}

\section{LIST OF PUBLICATIONS}

The following is the journals in which the manuscript will be submitted for publication:

Manuscript II: Water Sorption Behavior of Excipient Films

To be submitted for publication in European Journal of Pharmaceutical Sciences 


\section{APPENDIX B}

\section{DETAILS OF REGRESSION FOR GAB MODEL FITTING}

The following illustrates the nonlinear regression routine used along with the

regression report generated by Sigma Plot using adsorption data for hydroxypropyl

methylcellulose film at $\mathrm{T}=303 \mathrm{~K}$

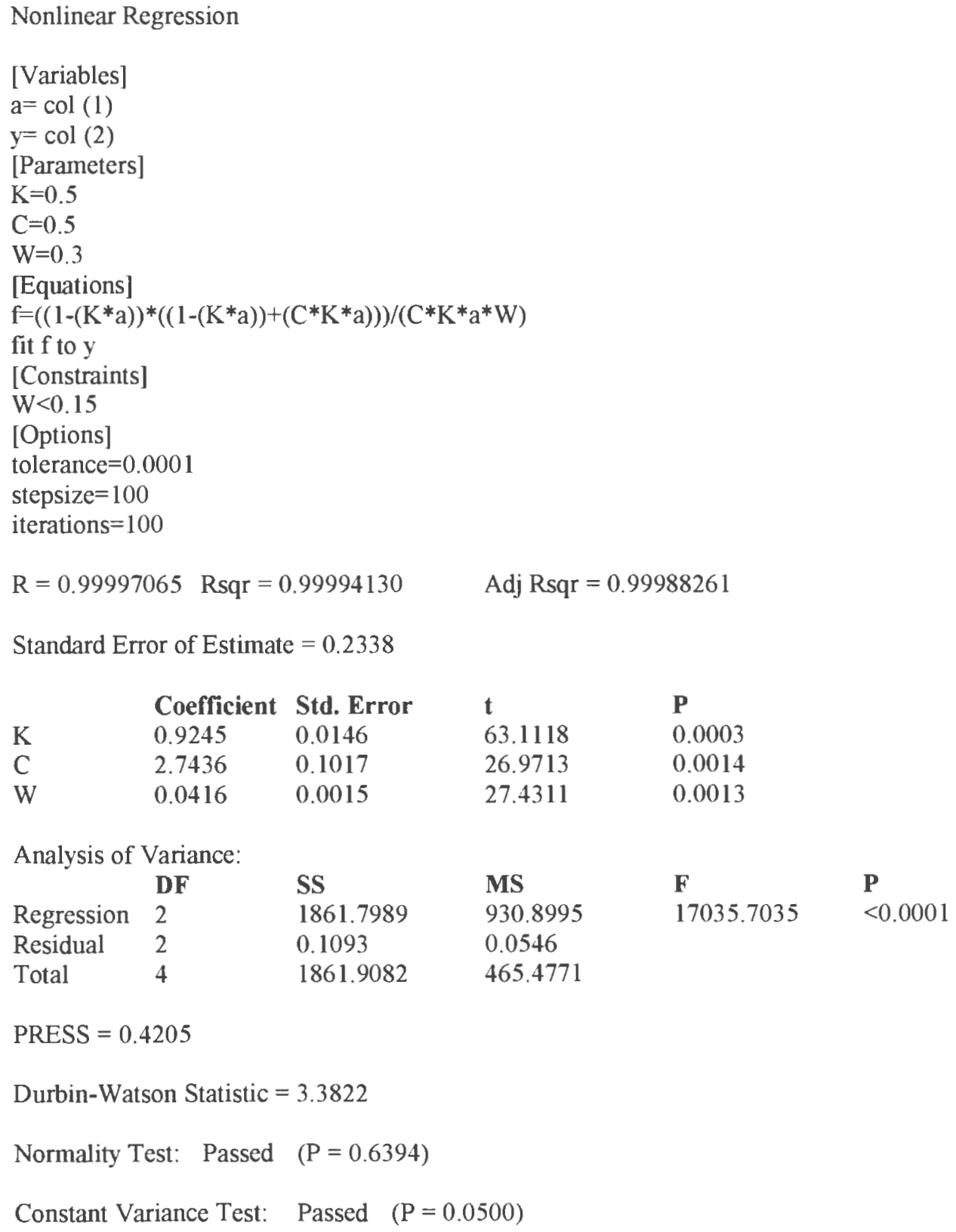


Power of performed test with alpha $=0.0500: 1.0000$

\begin{tabular}{|c|c|c|c|c|c|}
\hline \multicolumn{6}{|c|}{ Regression Diagnostics: } \\
\hline Row & Predicted & Residual & Std. Res. & Stud. Res. & Stud. Del. Res. \\
\hline 1 & 59.8763 & -0.0010 & -0.0041 & -0.0305 & -0.0216 \\
\hline 2 & 29.5943 & 0.0461 & 0.1973 & 0.2959 & 0.2139 \\
\hline 3 & 17.8993 & -0.1904 & -0.8146 & -1.0460 & -1.0990 \\
\hline 4 & 10.8511 & 0.2463 & 1.0538 & 1.2649 & 2.0000 \\
\hline 5 & 5.6616 & -0.1011 & -0.4324 & -0.8888 & -0.8080 \\
\hline \multicolumn{6}{|c|}{ Influence Diagnostics: } \\
\hline Row & Cook's Dis & Leverage & DFFITS & & \\
\hline 1 & 0.0170 & 0.9821 & -0.1598 & & \\
\hline 2 & 0.0364 & 0.5552 & 0.2390 & & \\
\hline 3 & 0.2365 & 0.3934 & -0.8851 & & \\
\hline 4 & 0.2351 & 0.3060 & 1.3280 & & \\
\hline 5 & 0.8493 & 0.7633 & -1.4510 & & \\
\hline \multicolumn{6}{|c|}{$95 \%$ Confidence } \\
\hline Row & Predicted & Regression $5 \%$ & Regression $95 \%$ & Population 5\% & Population 95\% \\
\hline 1 & 59.8763 & 58.8796 & 60.8730 & 58.4603 & 61.2923 \\
\hline 2 & 29.5943 & 28.8449 & 30.3437 & 28.3400 & 30.8486 \\
\hline 3 & 17.8993 & 17.2685 & 18.5302 & 16.7121 & 19.0866 \\
\hline 4 & 10.8511 & 10.2948 & 11.4075 & 9.7017 & 12.0005 \\
\hline 5 & 5.6616 & 4.7829 & 6.5404 & 4.3260 & 6.9972 \\
\hline
\end{tabular}




\section{APPENDIX C}

\section{DETAILS OF REGRESSION FOR YOUNG\&NELSON MODEL FITTING}

used

The following describes the segmented nonlinear regression routine

by SAS using data for hydroxypropyl methylcellulose at $\mathrm{T}=303 \mathrm{~K}$

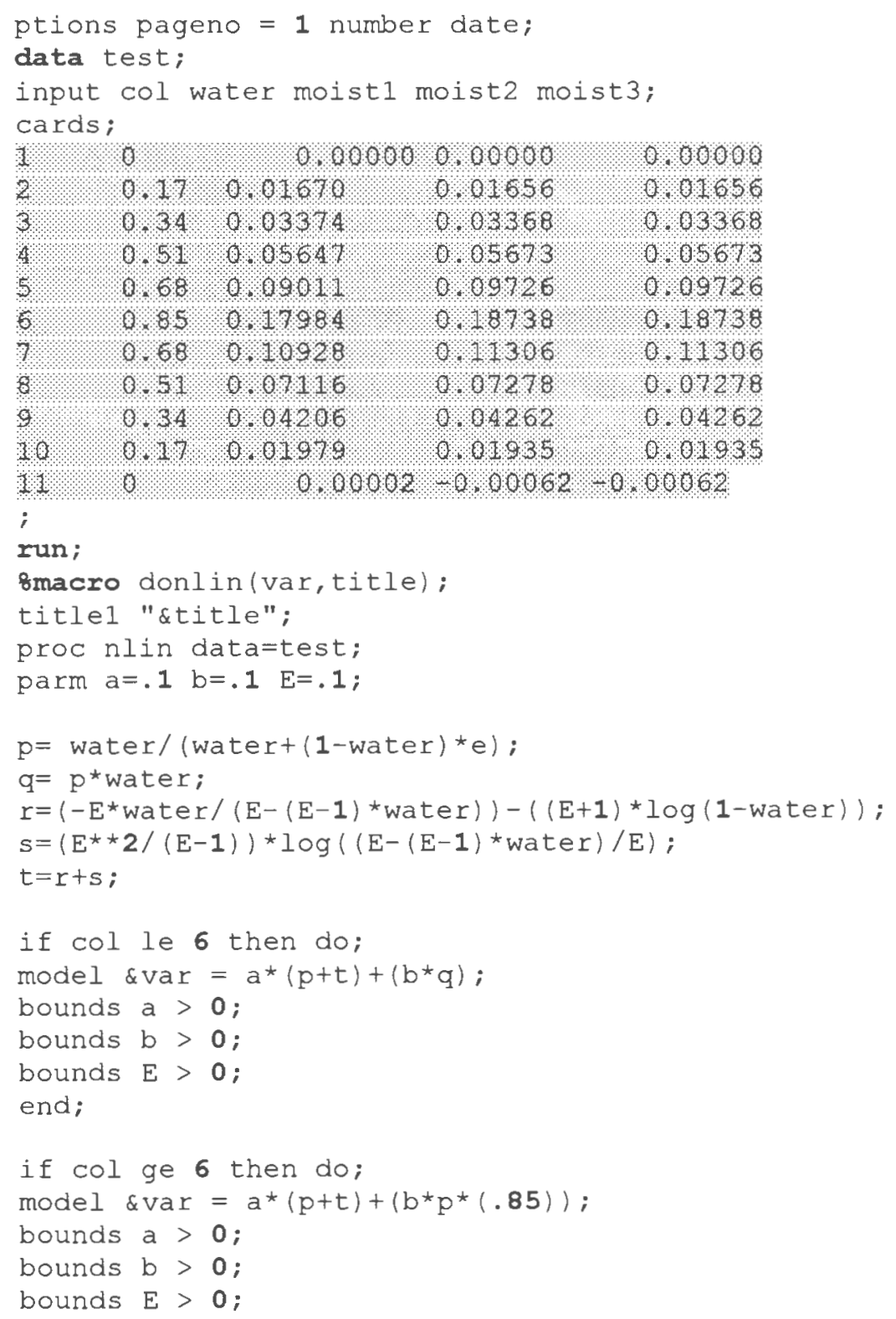




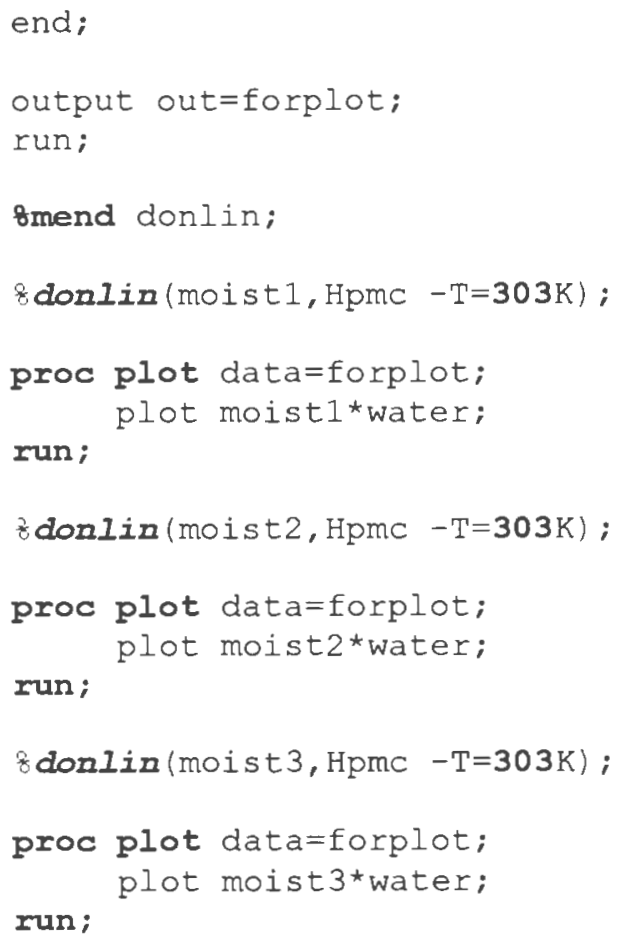




\section{SUMMARY OF CONCLUSIONS}

1) Dynamic vapor sorption technique is proven to be a simple, fast and convenient method for investigation of sorption and desorption behavior of excepient films of pharmaceutical significance. Films of hydroxypropyl methylcellulose, modified hydroxypropyl methylcellulose, microcrystaline cellulose have been used to examine the effect of temperature on moisture sorption/desorption studies.

2) All the three excepients showed type II isotherms and also hysteresis during desorption.

3) The sorption data of all three excepient films did not follow the simple Langmuir model

4) The BET model could be used restrictively.

5) The GAB, which is an extension of BET model, successfully described the data for all the three films at all water activities.

6) The hysteresis shown by all the three films could be modeled accurately using the Young and Nelson model, but meaningful interpretation of the model's parameters was not possible.

7) A complete thermodynamic analysis of water-excepient film interaction was performed. Partial molal free energies, enthalpies and entropies were computed for water-excepient film systems.

8) A comparative evaluation of the results of theoretical models and thermodynamic studies have shown that the results are not always complementary to each other, 
emphasizing the need to perform both analyses for complete characterization of water-excepient film systems.

9) It is also possible that the different states of water present can affect the functionality of the excepient. Water within the particles can strongly influence the compaction properties by affecting the degree of viscoelasticity. 


\section{BIBLIOGRAPHY}

Achanta A.S., Adusumilli P.S., James K.W. and Rhodes C.T., " Development of hot melt coating methods", Drug Development \& Industrial Pharmacy, 23: 441-449 (1997).

Achanta A.S., "Hot melt coating:Water sorption behaviour of excipient films" pg 31, M.S thesis, Univ. of Rhode Island, USA (1999)

Arroyo R., Cuesta C., Garrido-Polonio C., Lopez-Varela S. and Sanchez-Muniz F.J., "High-performance size exclusion chromatographic studies on polar components formed in sunflower oil used for frying", Journal of American Oil Chemists Society, 69(6): 557-563(1992).

Banker G.S and Rhodes C.T., Modern Pharmaceutics, Third Edition, Published by Marcel Dekker, New York (1996).

Barth H.G., Boyes B.E. and Jackson C., "Size exclusion chromatography", Analytical Chemistry, 66(12): 595R-620R (1994).

Bourret E., Ratsimbazafy V., Maury L. and Brossard C., "Rheological behavior of saturated polyglycolysed glycerides" Journal of Pharmacy and Pharmacology, 46:538-541 (1994).

Brittain H.G., Physical Characterization of Pharmaceutical Solids, Published by Marcel Dekker, New York (1995).

Busfield W.K. and Proschongo P.N., "Thermal analysis of palm stearine by DSC", Journal of American Oil Chemists Society, 67(3):171-175(1990). 
Busfeild W.K. and Proschongo P.N., "Hydrogenation of palm stearine: Changes in chemical composition and thermal properties", Journal of American Oil chemists Society, 67(3): 176-181(1990).

Callahan J.C., Cleary G.W., Elefant M., Kaplan G., Kensler T. and Nash R.A., "Equilibrium moisture content of pharmaceutical excipients", Drug Development \& Industrial Pharmacy, 8:335-369 (1982).

Carstensen J.T., Drug Stability, Principles and Practices, Published by Marcel Dekker, New York (1995).

Chan S. Y. and Pilpel N., "Absorption of moisture by sodium cromoglycate and mixtures of sodium cromoglycate and lactose", Journal of Pharmacy and Pharmacology, 35: 477-481 (1983).

Coben L.J., and Lordi N.G., "Physical stability of semisynthetic suppository bases", Journal of Pharmaceutical Sciences, 69(8): 995-960 (1980).

Copeland L.E., and Young T.F., " A Thermodynamic theory of adsorption", Advances in Chemistry Series, 33: 348-355 (1961).

Craig D.Q.M. and Newton J.M., "Characterisation of polyethylene glycols using differential scanning calorimetry", International Journal of Pharmaceutics, 74: 33$41(1991)$.

Craig D.Q.M., "A review of thermal methods used for the analysis of the crystal form, solution thermodynamics and glass transition behaviour of polyethylene glycols", Thermochimica Acta, 248: 189-203 (1995). 
DeMan L., deMan J. M., and Blackman B., " Polymorphic behavior of some fully hydrogenated oils and their mixtures with liquid oil", Journal of American Oil Chemists Society, 66(12): 1777-1780 (1989).

Duddu S.P., and Grant D.J.W., "The use of thermal analysis in the assessment of crystal disruption", Thermochimica Acta, 248: 131-145 (1995).

Flaherty B., " Characterisation of waxes by differential scanning calorimetry", Journal of Applied Chemistry and Biotechnology, 21:144-148 (1971).

Ghebre-Sellassie I., Multiparticulate Oral Drug Delivery, Published by Marcel Dekker, New York (1994).

Gines J. M., Veiga M.D., Arias M.J. and Rabasco A.M., " Elaboration and thermal study of interactions between cinnarizine and gelucire $^{(3)} 53 / 10$ physical mixtures and solid dispersions" International Journal of Pharmaceutics, 126:287-291 (1995).

Hegemann J.W., Tallent W.H. and Kolb K.E., "Differential scanning calorimetry of single acid triglycerides: Effect of chain length and unsaturation", Journal of American Oil Chemists Society, 49:1 18-123 (1972).

Hollenbeck R.G., Peck G.E. and Kildsig D.O., "Application of immersional calorimetry to investigation of solid-liquid interactions: microcrystalline cellulosewater system", Journal of Pharmaceutical Sciences, 67: 1599-1606 (1978).

Husain S., Sastry G.S.R. and Raju N.P., "Molecular weight averages as criteria for quality assessment of heated oils and fats", Journal of American Oil Chemists Society, 68(11): 822-826 (1991). 
Khan F. and Pilpel N., "An investigation of moisture sorption in microcrystalline cellulose using sorption isotherms and dielectric response", Powder Technology, 50: 237-241 (1987).

Kotsiomiti E. and McCabe J.F., " Stability of dental waxes following repeated heatings", Journal of Oral Rehabilitation, 22: 135-143 (1995).

Labuza T.P., " Sorption phenomena in foods", Food Technology, 22: 263-272 (1968).

Lachman L., Lieberman H.A. and Kanig J.L, The Theory and Practice of Industrial Pharmacy, Third Edition, Published by Lea \& Febiger, Philadelphia (1986).

Letoffe J.M., Claudy P., Kok M.V., Garcin M. and Volle J.L., " Crude oils: characterization of waxes precipitated on cooling by DSC and thermomicroscopy", Fuel, 74(6): 810-817 (1995).

Liverisidge G.G., Grant D.J.W. and Padfield J.M., " Drug-excipient interactions and polymorphism in triglyceride suppository formulations", Analytical Proceedings, 549-532 (1982).

Malamataris S. and Dimitriou A., "Moisture sorption profiles and tensile strength of tableted phenobarbitone formulations", Journal of Pharmacy and Pharmacology, 42: $158-163(1990)$.

Malamataris S., Goidas P. and Dimitriou A., "Moisture sorption and tensile strength of some tableted direct compression excipients", International Journal of Pharmaceutics, 68: 51-60 (1991).

Matin A. and Bustamante P., Physical Pharmacy, Fourth Edition, Published by Lea \& Febiger, Philadelphia (1993). 
McGinity J.W., Aqueous Polymeric Coatings for Pharmaceutical Dosage Forms, Second Edition, Published by Marcel Dekker, New York (1997).

Sadeghnejad G.R., York P. and Stanley-Wood N.G., "Water vapor interaction with cellulose powders", Drug Development \& Industrial Pharmacy, 12: 2171-2192 (1996).

Sanchez-Miniz F.J., Cuesta and Garrido-Polonio C., "Sunflower oil used for frying: Combination of column, gas and high-performance size-exclusion chromatography for its evaluation", Journal of American Oil Chemists Society, 70(3): 235-240 (1993). Simon K. and Suverkrup R., "Comparison of recent techniques to characterize the crystallization behaviour of fatty suppository bases", Thermochimica Acta, 248: 271287 (1995).

Strickland W.A., "Study of water vapor sorption by pharmaceutical powders", Journal of Pharmaceutical Sciences, 51:310-314 (1962).

Sutananta W., Craig D.Q.M. and Newton J.M., "An investigation into the structure and stability of gelucire $43 / 01$ using differential scanning calorimetry and optical microscopy", Journal of Pharmacy and Pharmacology, 45(S2): 1099 (1993)

Sutananta W., Craig D.Q.M. and Newton J.M., "The effects of ageing on the thermal behaviour and mechanical properties of pharmaceutical glycerides", International Journal of Pharmaceutics, 111: 51-62 (1994).

Tabibi S.E., "Water vapor adsorption by compressible sugar and its effect on powder compressibility", Ph.D. Thesis, University of Maryland, USA (1982).

Tabibi S.E. and Hollenbeck R.G., "Interaction of water vapor and compressible sugar", International Journal of Pharmaceutics, 18: 169-183 (1984). 
United States Pharmacopeia 23/National Formulary 18, The United States Pharmacopeial Convention, Rockville (1995).

Wurster D.E., Peck G.E. and Kildsig D.O., "A comparison of the moisture adsorption-desorption properties of corn starch, USP and directly compressible starch", Drug Development \& Industrial Pharmacy, 8: 343-354 (1982)

Yap P.H., deMan J.M. and deMan L., "Polymorphism of palm oil and palm oil products", Journal of American Oil Chemists Society, 66(5): 693-697 (1989).

York P., "Analysis of moisture sorption hysteresis in hard gelatin capsules, maize starch, and maize starch:drug powder mixtures", Journal of Pharmacy and Pharmacology, 33: 269-273 (1981).

York P., "Solid state properties of powders in the formulation and processing of solid dosage forms", International Journal of Pharmaceutics, 14: 1-28 (1983).

Young J.H. and Nelson G.L., "Theory of hysteresis between sorption and desorption isotherms in biological materials", Transactions of the American Society of Agricultural Engineers, 10: 260-263 (1967).

Young J.H. and Nelson G.L., "Research of hysteresis between sorption and desorption isotherms of wheat", Transactions of the American Society of Agricultural Engineers, 10: 756-761 (1967). 